Check for updates

Cite this: Nanoscale Adv., 2019, 1, 2965

\title{
Fe(II) and Fe(III) dithiocarbamate complexes as single source precursors to nanoscale iron sulfides: a combined synthetic and in situ XAS approach + t.
}

\author{
Anna Roffey, (D) ab Nathan Hollingsworth, Husn-Ubayda Islam, bc Wim Bras, (D) cd

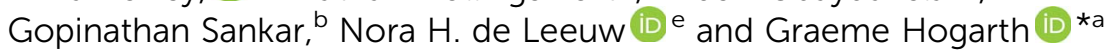

\begin{abstract}
Nanoparticulate iron sulfides have many potential applications and are also proposed to be prebiotic catalysts for the reduction of $\mathrm{CO}_{2}$ to biologically important molecules, thus the development of reliable routes to specific phases with controlled sizes and morphologies is important. Here we focus on the use of iron dithiocarbamate complexes as single source precursors (SSPs) to generate greigite and pyrrhotite nanoparticles. Since these minerals contain both iron(III) and iron(II) centres, SSPs in both oxidation states, $\left[\mathrm{Fe}\left(\mathrm{S}_{2} \mathrm{CNR}_{2}\right)_{3}\right]$ and cis- $\left[\mathrm{Fe}(\mathrm{CO})_{2}\left(\mathrm{~S}_{2} \mathrm{CNR}_{2}\right)_{2}\right]$ respectively, have been utilised. Use of this $\mathrm{Fe}(I)$ precursor is novel and it readily loses both carbonyls in a single step (as shown by TGA measurements) providing an in situ source of the extremely air-sensitive $\mathrm{Fe}(I I)$ dithiocarbamate complexes $\left[\mathrm{Fe}\left(\mathrm{S}_{2} \mathrm{CNR}_{2}\right)_{2}\right]$. Decomposition of $\left[\mathrm{Fe}\left(\mathrm{S}_{2} \mathrm{CNR}_{2}\right)_{3}\right]$ alone in oleylamine affords primarily pyrrhotite, although by careful control of reaction conditions (ca. $230{ }^{\circ} \mathrm{C}, 40-50 \mathrm{nM}$ SSP) a window exists in which pure greigite nanoparticles can be isolated. With cis- $\left[\mathrm{Fe}(\mathrm{CO})_{2}\left(\mathrm{~S}_{2} \mathrm{CNR}_{2}\right)_{2}\right]$ we were unable to produce pure greigite, with pyrrhotite formation dominating, a similar situation being found with mixtures of $\mathrm{Fe}(I)$ and $\mathrm{Fe}(\mathrm{II})$ precursors. In situ X-ray absorption spectroscopy (XAS) studies showed that heating $\left[\mathrm{Fe}\left(\mathrm{S}_{2} \mathrm{CN}^{i} \mathrm{Bu}_{2}\right)_{3}\right]$ in oleylamine resulted in amine coordination and, at ca. $60{ }^{\circ} \mathrm{C}$, reduction of $\mathrm{Fe}($ III) to $\mathrm{Fe}(I I)$ with (proposed) elimination of thiuram disulfide $\left(\mathrm{S}_{2} \mathrm{CNR}_{2}\right)_{2}$. We thus carried out a series of decomposition studies with added thiuram disulfide $\left(\mathrm{R}={ }^{\mathrm{i}} \mathrm{Bu}\right)$ and found that addition of $1-2$ equivalents led to the formation of pure greigite nanoparticles between 230 and $280{ }^{\circ} \mathrm{C}$ with low SSP concentrations. Average particle size does not vary significantly with increasing concentration, thus providing a convenient route to ca. $40 \mathrm{~nm}$ greigite nanoparticles. In situ XAS studies have been carried out and allow a decomposition pathway for $\left[\mathrm{Fe}\left(\mathrm{S}_{2} \mathrm{CN}^{\prime} \mathrm{Bu}_{2}\right)_{3}\right]$ in oleylamine to be established; reduction of $\mathrm{Fe}(\mathrm{III})$ to $\mathrm{Fe}(\mathrm{II})$ reduction triggers substitution of the secondary amide backbone by oleylamine $\left(\mathrm{RNH}_{2}\right)$ resulting in the in situ formation of a primary dithiocarbamate derivative $\left[\mathrm{Fe}\left(\mathrm{RNH}_{2}\right)_{2}\left(\mathrm{~S}_{2} \mathrm{CNHR}\right)_{2}\right]$. This in turn extrudes RNCS to afford molecular precursors of the observed FeS nanomaterials. The precise role of thiuram disulfide in the decomposition process is unknown, but it likely plays a part in controlling the $\mathrm{Fe}(\mathrm{III})-\mathrm{Fe}(I)$ equilibrium and may also act as a source of sulfur allowing control over the $\mathrm{Fe}: \mathrm{S}$ ratio in the mineral products.
\end{abstract}

Received 23rd April 2019 Accepted 5th June 2019

DOI: $10.1039 / c 9 n a 00262 f$

rsc.li/nanoscale-advances

\section{Introduction}

${ }^{a}$ Department of Chemistry, King's College London, Britannia House, 7 Trinity Street, London SE1 1DB, UK

${ }^{b}$ Department of Chemistry, University College London, 20 Gordon Street, London WC1H OAJ, UK

'Netherlands Organisation for Scientific Research DUBBLE@ESRF, 38043 Grenoble, France

${ }^{d}$ Chemistry Division, Oak Ridge National Laboratory, Oak Ridge, Tennessee 37831, USA

${ }^{e}$ School of Chemistry, Cardiff University, Main Building, Park Place, Cardiff, CF10 $3 A T, U K$

$\dagger$ Dedicated to the memory of Professor Paul O'Brien CBE FRS FREng FRSC (1954-2018) an outstanding person and talented chemist who pioneered the use of dithiocarbamate complexes as single source precursors.

\$ Electronic supplementary information (ESI) available. See DOI: $10.1039 / \mathrm{c} 9 \mathrm{na00262f}$
Several phases of iron sulfide are known including; mackinawite (FeS), troilite (FeS) greigite $\left(\mathrm{Fe}_{3} \mathrm{~S}_{4}\right)$, pyrrhotite $\left(\mathrm{Fe}_{1-x} \mathrm{~S}\right.$, commonly $\mathrm{Fe}_{7} \mathrm{~S}_{8}$ and $\mathrm{Fe}_{8} \mathrm{~S}_{9}$ ), marcasite (orthorhombic $\mathrm{FeS}_{2}$ ) and pyrite (cubic $\mathrm{FeS}_{2}$ ). While some contain only $\mathrm{Fe}(\mathrm{II})$ others, such as greigite, contain both $\mathrm{Fe}(\mathrm{II})$ and $\mathrm{Fe}(\mathrm{III}) .{ }^{1}$ Nanoscale iron sulfides have potential applications as hydrogen evolution catalysts, ${ }^{2}$ semiconductor materials for solar cells, ${ }^{3,4}$ photodiode materials, ${ }^{5}$ photocatalysts and sensors, ${ }^{6}$ information storage, ${ }^{7}$ and in biomedicine. ${ }^{8-10}$ They are also implicated in prebiotic chemistry, ${ }^{\mathbf{1 1} 12}$ a widely considered hypothesis being that iron sulfides in the chimney cavities of hydrothermal vents ${ }^{13}$ catalysed $\mathrm{CO}_{2}$ reduction forming a primitive acetyl-CoA pathway similar to that in contemporary enzymes. ${ }^{\mathbf{1 4 - 1 6}}$ Greigite is 
structurally similar to the $\mathrm{Fe}_{4} \mathrm{~S}_{4}$ cluster sub-units found in ferredoxins ${ }^{17}$ which have been shown to act as electron-transfer sites and to be catalytically active centers for molecular transformations. ${ }^{18}$ These enzymes are highly product-specific and efficient, as shown for example in formate dehydrogenases, which are able to reduce $\mathrm{CO}_{2}$ to formate under moderate conditions. ${ }^{19-24}$ The catalytic nature of greigite in $\mathrm{CO}_{2}$ activation has been demonstrated, ${ }^{25,26}$ while iron sulfides have also been shown to catalyse $\mathrm{CO}_{2}$ reduction ${ }^{27}$ which in the presence of $\mathrm{H}_{2} \mathrm{~S}$ can lead to a range of thiols. ${ }^{28}$

In a recent perspective review, ${ }^{29} \mathrm{O}^{\prime}$ Brien and co-workers considered three methods for the synthesis of nanoparticulate iron sulfides; hydrothermal, solvent-free and solvothermal processes. The latter, which utilise single source precursors (SSPs), are particularly attractive as the ratio of iron to sulfur can be tuned. ${ }^{30-45}$ In 2008 , O'Brien reported that solvothermal decomposition of $\left[\mathrm{N}^{n} \mathrm{Bu}_{4}\right]_{2}\left[\mathrm{Fe}_{4} \mathrm{~S}_{4}(\mathrm{SPh})_{4}\right]$ provided a convenient route to iron sulfide nanomaterials, tuning of the reaction medium and temperature leading to selective formation of different phases. ${ }^{37}$ Thus at $180{ }^{\circ} \mathrm{C}$ in octylamine, pyrrhotite nanoparticles result, while at $230{ }^{\circ} \mathrm{C}$ in oleylamine greigite nanoparticles are formed. That pyrrhotite is generated at low and greigite at high temperatures is particularly interesting as the cluster SSP has an $\mathrm{Fe}_{4} \mathrm{~S}_{4}$ core that is similar to the repeating unit of greigite. Thus it is feasible that the molecular geometry of the precursor directs the nanoparticle growth at higher temperatures where decomposition is fast. In related work, Tilley and co-workers reported the synthesis of greigite nanocrystals from the hotinjection of $\left[\left\{\mathrm{Fe}(N \text {-MeIm })_{6}\right\} \mathrm{S}_{8}\right] \quad(N$-MeIm $=N$-methylimidazole) into oleylamine at $300{ }^{\circ} \mathrm{C} .{ }^{38}$ Heating the same SSP for longer periods gave mixtures of greigite and pyrrhotite, while upon prolonged heating $(4 \mathrm{~h})$ sub-micrometer crystallites of pure pyrrhotite were formed, suggesting that pyrrhotite was the thermally stable phase. ${ }^{46}$ While these approaches are elegant, the SSPs used are not easy to prepare and handle and it would be advantageous to develop SSPs that can be easily synthesised from cheap, readily available, starting materials and are air and moisture stable.

Dithiocarbamate $\left(\mathrm{S}_{2} \mathrm{CNR}_{2}\right)$ complexes potentially provide such SSPs as the ligands themselves are easily prepared from secondary amines and $\mathrm{CS}_{2}$ under basic conditions in water. ${ }^{47}$ Further, $\mathrm{Fe}(\mathrm{III})$ complexes $\left[\mathrm{Fe}\left(\mathrm{S}_{2} \mathrm{CNR}_{2}\right)_{3}\right]$, are air-stable crystalline solids formed in high yields upon addition of iron salts to aqueous solutions of dithiocarbamates. ${ }^{47}$ Iron sulfides generally contain $\mathrm{Fe}(\mathrm{II})$, and a range of $\mathrm{Fe}(\mathrm{II})$ dithiocarbamate complexes of the type $\left[\mathrm{Fe}\left(\mathrm{S}_{2} \mathrm{CNR}_{2}\right)_{2} \mathrm{~L}_{2}\right]$ (e.g. $\mathrm{L}=\mathrm{CO} ; \mathrm{L}_{2}=1,10$ phen) are known. ${ }^{48-52}$ In 2008, Gao first reported the use of iron dithiocarbamate complexes as SSPs, detailing the effects of decomposition temperature and solvent on $\mathrm{Fe}(\mathrm{II})\left[\mathrm{Fe}\left(\mathrm{S}_{2}\right.\right.$ $\left.\mathrm{CNEt}_{2}\right)_{2}(1,10$-phen) $]$ and $\mathrm{Fe}(\mathrm{III})\left[\mathrm{Fe}\left(\mathrm{S}_{2} \mathrm{CNEt}_{2}\right)_{3}\right]$ complexes. $^{\mathbf{4 1}}$ When $\left[\mathrm{Fe}\left(\mathrm{S}_{2} \mathrm{CNEt}_{2}\right)_{2}(1,10\right.$-phen $\left.)\right]$ was decomposed in oleylamine for $5 \mathrm{~min}$ at $\mathrm{ca} \cdot 260-300{ }^{\circ} \mathrm{C}$, hexagonal nanosheets of pyrrhotite (monoclinic) were produced, while at high temperatures $\left(320{ }^{\circ} \mathrm{C}\right)$ troilite (hexagonal $\mathrm{FeS}$ ) resulted. In contrast, decomposition of $\left[\mathrm{Fe}\left(\mathrm{S}_{2} \mathrm{CNEt}_{2}\right)_{3}\right]$ in oleylamine gave a mixture of pyrrhotite and greigite at all temperatures below
$300{ }^{\circ} \mathrm{C}$, but at $320{ }^{\circ} \mathrm{C}$ pure pyrrhotite nanosheets resulted. ${ }^{41} \mathrm{~A}$ closely related study by $\mathrm{Xu}$, Wang and co-workers investigated the effects of solvent on the decomposition of $\left[\mathrm{Fe}\left(\mathrm{S}_{2}\right.\right.$ $\left.\mathrm{CNEt}_{2}\right)_{2}(1,10$-phen) $]$ and $\left[\mathrm{Fe}\left(\mathrm{S}_{2} \mathrm{CNEt}_{2}\right)_{3}\right] \cdot{ }^{42}$ Decomposition of $\left[\mathrm{Fe}\left(\mathrm{S}_{2} \mathrm{CNEt}_{2}\right)_{3}\right]$ in oleylamine/octadecane mixtures $(1: 1)$ afforded greigite nanosheets, while decomposition of $\left[\mathrm{Fe}\left(\mathrm{S}_{2}-\right.\right.$ $\left.\mathrm{CNEt}_{2}\right)_{2}(1,10$-phen)] under similar conditions gave pyrrhotite nanosheets. ${ }^{42}$ More recently, O'Brien reported on the effects of temperature, solvent and ligand substituents on the decomposition of $\left[\mathrm{Fe}\left(\mathrm{S}_{2} \mathrm{CNR}_{2}\right)_{3}\right] \mathrm{SSPs}^{.53}$

In developing catalysts for electrocatalytic $\mathrm{CO}_{2}$ reduction ${ }^{25}$ we sought to expand on the work described above to prepare iron sulfide nanomaterials, in particular greigite, varying both particle phase, morphology and size. A key feature of greigite is the presence of both $\mathrm{Fe}$ (II) and $\mathrm{Fe}(\mathrm{III})$ centres, being an inverse spinel $\mathrm{A}(\mathrm{AB}) \mathrm{S}_{4}$ with $\mathrm{Fe}(\mathrm{II})$ in the tetrahedral A sites and both $\mathrm{Fe}(\mathrm{II})$ and Fe(III) in octahedral B sites. Thus it seemed likely that a successful solvothermal approach would be the decomposition of a mixture of $\mathrm{Fe}(\mathrm{II})$ and $\mathrm{Fe}(\mathrm{III})$ SSPs. Like others we have also used $\mathrm{Fe}(\mathrm{III})$ complexes, $\left[\mathrm{Fe}\left(\mathrm{S}_{2} \mathrm{CNR}_{2}\right)_{3}\right]$, as $\mathrm{Fe}(\mathrm{III})$ SSPs but utilise readily prepared dicarbonyl complexes cis- $\left[\mathrm{Fe}(\mathrm{CO})_{2}\left(\mathrm{~S}_{2^{-}}\right.\right.$ $\left.\mathrm{CNR}_{2}\right)_{2}$ ] as $\mathrm{Fe}(\mathrm{II}) \mathrm{SSPs}$, as they readily lose both carbonyls upon heating. We also find that heating $\left[\mathrm{Fe}\left(\mathrm{S}_{2} \mathrm{CNR}_{2}\right)_{3}\right]$ in amines results in intramolecular electron transfer resulting in generation of otherwise difficult to access $\mathrm{Fe}(\mathrm{II})$ bis(dithiocarbamate) complexes, $\left[\mathrm{Fe}\left(\mathrm{S}_{2} \mathrm{CNR}_{2}\right)_{2}\right]$, and the oxidised form of dithiocarbamate namely thiuram disulfide, We can then exploit this by addition of added thiuram disulfide to the decomposing mixture leading to significant differences in products distributions from the same SSP precursors.

\section{Results and discussion}

\section{(i) Synthesis and characterisation of $\left[\mathrm{Fe}\left(\mathrm{S}_{2} \mathrm{CNR}_{2}\right)_{3}\right]$ and cis- $\left[\mathrm{Fe}(\mathrm{CO})_{2}\left(\mathrm{~S}_{2} \mathrm{CNR}_{2}\right)_{2}\right]$}

The choice of $\mathrm{Fe}(\mathrm{III})$ SSPs was straightforward since $\left[\mathrm{Fe}\left(\mathrm{S}_{2}\right.\right.$ $\left.\mathrm{CNR}_{2}\right)_{3}$ ] are easily prepared according to well-established literature methods. ${ }^{54}$ Addition of $c a .3$ equivalents of $\mathrm{Na}\left(\mathrm{S}_{2} \mathrm{CNR}_{2}\right)$ to an aqueous solution of $\mathrm{FeCl}_{3}$ giving $\left[\mathrm{Fe}\left(\mathrm{S}_{2} \mathrm{CNR}_{2}\right)_{3}\right](\mathbf{1 a}-\mathbf{d})$ as black-brown solids after work up (Scheme 1).

For an Fe(II) SSP we initially considered bis(dithiocarbamate) complexes, $\left[\mathrm{Fe}\left(\mathrm{S}_{2} \mathrm{CNR}_{2}\right)_{2}\right]$, first prepared in 1950 (ref. 55) as chocolate-brown solids, ${ }^{56,57}$ while in 1975 Ileperuma and Feltham reported the crystal structure of $\left[\mathrm{Fe}\left(\mathrm{S}_{2} \mathrm{CNEt}_{2}\right)_{2}\right]^{58}$ the metal centre being square planar. They are, however, extremely air sensitive, being rapidly oxidised to $\left[\mathrm{Fe}\left(\mathrm{S}_{2} \mathrm{CNR}_{2}\right)_{3}\right]$. The $\mathrm{Fe}(\mathrm{II})$ centre can be stabilised by addition of bidentate donor ligands such as 1,10-phenanthroline (phen), 2,2-bipyridine (bipy) ${ }^{\mathbf{4 8 , 5 2 , 5 9}}$ and 1,2-bis(diphenylphosphino)ethane (dppe). ${ }^{51}$ While these complexes may be able to act as Fe(II) SSPs, their high molecular weights and the non-volatile nature make them less desirable. In contrast, carbonyl derivatives, cis- $\left[\mathrm{Fe}(\mathrm{CO})_{2}\left(\mathrm{~S}_{2} \mathrm{CNR}_{2}\right)_{2}\right](2)$, are relatively air stable and can be prepared via a number of methods. ${ }^{52,60,61}$ We used a route developed by Dean ${ }^{61}$ involving reaction of cis-[Fe(CO) $\left.)_{4} \mathrm{I}_{2}\right]$ with two equivalents of dithiocarbamate salt. Initially the sodium salts were used but their poor solubility in organic solvents led to long reaction times and thus 


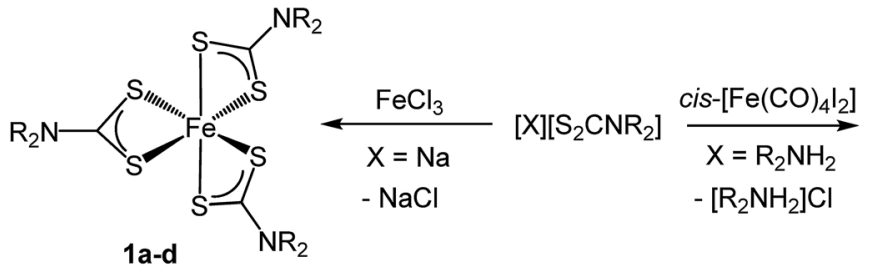

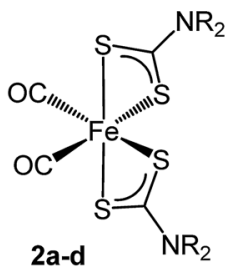

a $\mathrm{R}=\mathrm{Me}$

b $R=E t$

c $R={ }^{i} \mathrm{Bu}$

$\mathrm{d} \mathrm{R}^{1}=\mathrm{Me}, \mathrm{R}^{2}={ }^{\mathrm{n}} \mathrm{Bu}$

Scheme 1 Synthesis of $\left[\mathrm{Fe}\left(\mathrm{S}_{2} \mathrm{CNR}_{2}\right)_{3}\right](1 \mathrm{a}-\mathrm{d})$ and cis- $\left[\mathrm{Fe}(\mathrm{CO})_{2}\left(\mathrm{~S}_{2} \mathrm{CNR}_{2}\right)_{2}\right](2 \mathrm{a}-\mathrm{d})$.

ammonium dithiocarbamate salts, $\left[\mathrm{R}_{2} \mathrm{NH}_{2}\right]\left[\mathrm{S}_{2} \mathrm{CNR}_{2}\right]$, were adopted instead. These were prepared upon reaction of $\mathrm{CS}_{2}$ with two equivalents of the chosen secondary amine and were fully characterised (see ESI $\$$ ). Addition of $c a .2$ equivalents of $\left[\mathrm{R}_{2} \mathrm{NH}_{2}\right]$ $\left[\mathrm{S}_{2} \mathrm{CNR}_{2}\right]$ to cis- $\left[\mathrm{Fe}(\mathrm{CO})_{4} \mathrm{I}_{2}\right]$ in $\mathrm{Et}_{2} \mathrm{O} / \mathrm{CH}_{2} \mathrm{Cl}_{2}$ at room temperature slowly (ca. $18 \mathrm{~h}$ ) afforded cis-[Fe(CO) $\left.)_{2}\left(\mathrm{~S}_{2} \mathrm{CNR}_{2}\right)_{2}\right](\mathbf{2 a - d})$ in moderate $(30-45 \%)$ yields after work-up. For $2 \mathrm{c}$ an excess of dithiocarbamate salt was used and this increased the rate of reaction dramatically. IR spectroscopy confirmed the presence of two carbonyls in a cis conformation, all exhibiting two peaks at $c a .2025$ and $1965 \mathrm{~cm}^{-1}$ being close to values previously reported. ${ }^{48}$ By fast atom bombardment (FAB) mass spectrometry, only in the case of $\mathbf{2 a}$ was the intact molecular ion observed; in all other cases the heaviest ion was $\left[\mathrm{Fe}\left(\mathrm{S}_{2} \mathrm{CNR}_{2}\right)_{2}\right]$, suggesting that loss of both carbonyls is a facile process, supporting our hypothesis that such complexes would be good Fe(II) precursors.

\section{(ii) Thermogravimetric analysis (TGA)}

Although not directly comparable to the solvothermal decomposition work (carried out in a coordinating solvent/capping agent which plays a significant role in the decomposition process-mechanism) TGA nevertheless provides useful information on the likely appropriateness of an SSP.

TGA graphs (Fig. 1) for 1a and 1c are similar, showing thermal stability below $\mathrm{ca} .300{ }^{\circ} \mathrm{C}$, whereupon there is a sharp mass loss, a residual mass of $c a$. $3-5 \%$ remains, indicating probable sublimation. DSC for $1 \mathrm{c}$ shows a small peak at $170{ }^{\circ} \mathrm{C}$ indicative of melting, but no such peak is seen for 1a. Both graphs are complicated by several overlapping peaks, indicating a multistep process. TGA data for $\mathbf{1 b}$ and $\mathbf{1 d}$ differ are superficially similar, both leaving a residual mass approximately of $c a$. $20 \%$, being close to that expected for FeS. They are some significant differences between the two. 1b initially decomposes between $226-277{ }^{\circ} \mathrm{C}$ losing $73 \%$ of its mass, followed by the gradual loss of a further $5 \%$ up to $500{ }^{\circ} \mathrm{C}$ which corresponds to the loss of a further sulfur. This differs slightly from previous work by O'Brien et al., who observed a single mass loss of $79 \%$ between $\mathrm{ca}$. $220-300{ }^{\circ} \mathrm{C}$ when they performed TGA on $\mathbf{1 b}$, with no further losses up to $500{ }^{\circ} \mathrm{C} .{ }^{53}$ The methyl-butyl derivative, 1d, decomposes between $c a .175-320{ }^{\circ} \mathrm{C}$ with $c a$. $81 \%$ of the mass lost. This a wider range of decomposition and a markedly lower starting temperature indicating instability due to the unsymmetrical ligand. At first glance, TGA graphs for 2a-d (Fig. 2) look
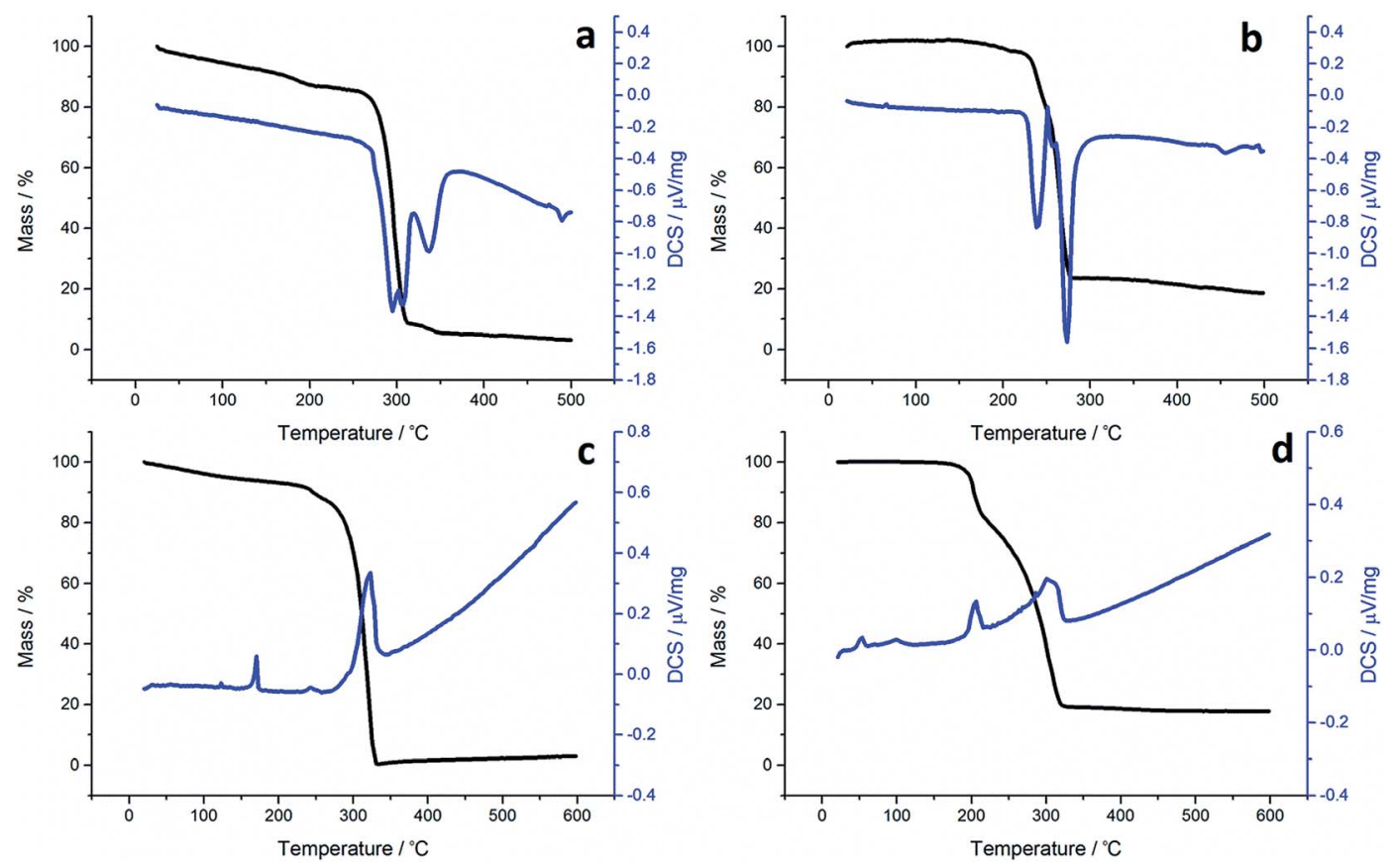

Fig. 1 TGA (black) and DSC (blue) graphs for (a) 1a, (b) 1b, (c) 1c and (d) $1 \mathrm{~d}$. 

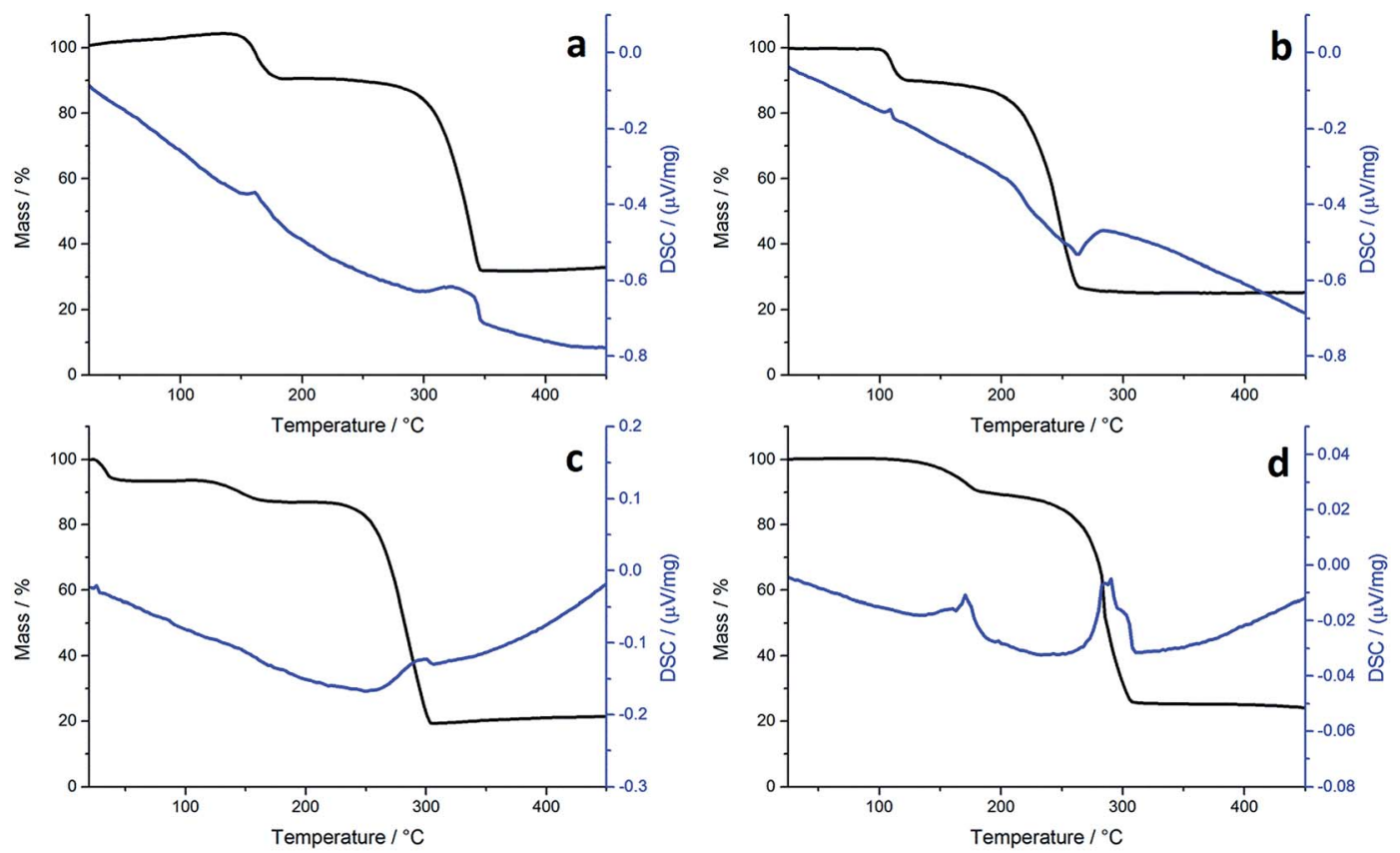

Fig. 2 TGA (black) and DSC (blue) graphs for (a) 2a, (b) 2b, (c) 2c and (d) 2d

similar, each showing a small mass loss at $c a .150{ }^{\circ} \mathrm{C}$, followed by a much greater mass loss at $c a .250^{\circ} \mathrm{C}$. Both processes are sharp but occur at a temperature that is dependent on the substituents. Complex $2 \mathbf{c}$ appears to exhibit an additional mass loss between $25-37{ }^{\circ} \mathrm{C}$, but this can be accounted for by the presence of co-crystallised $n$-pentane (bp $\left.36{ }^{\circ} \mathrm{C}\right)$.

In all TGA graphs the initial mass decrease at $c a .150{ }^{\circ} \mathrm{C}$ is attributed to the loss of both carbonyls. This is followed by a period of thermal stability for the putative $\left[\mathrm{Fe}\left(\mathrm{S}_{2} \mathrm{CNR}_{2}\right)_{2}\right]$ before it decomposes in a sharp curve. This indicates that all complexes exhibit a level of stability required for solvothermal synthesis i.e. they are stable at room temperature and can be delivered to the decomposition chamber, but the carbonyl ligands are labile and dissociate in a single step at a temperature lower than that at which $\left[\mathrm{Fe}\left(\mathrm{S}_{2} \mathrm{CNR}_{2}\right)_{2}\right]$ decomposes. Consistent with mass spectral data, the most thermally stable dicarbonyl is $\mathbf{2 a}$, which only begins to lose its carbonyls at $c a$. $144{ }^{\circ} \mathrm{C}$. Likewise $\left[\mathrm{Fe}\left(\mathrm{S}_{2} \mathrm{CNMe}_{2}\right)_{2}\right]$ is also the most thermally stable of the simple Fe(II) complexes, decomposing at $c a .266^{\circ} \mathrm{C}$, some $44{ }^{\circ} \mathrm{C}$ higher than the next most stable fragment, $\left[\mathrm{Fe}\left(\mathrm{S}_{2^{-}}\right.\right.$ $\left.\left.\mathrm{CN}^{\mathrm{i}} \mathrm{Bu}_{2}\right)_{2}\right]$. Decomposition of $\left[\mathrm{Fe}\left(\mathrm{S}_{2} \mathrm{CNMe}_{2}\right)_{2}\right]$ begins at a similar temperature to the $\mathrm{Fe}(\mathrm{III})$ analogue 1a, indicating similar stability. However, while virtually nothing was left of $\mathbf{1 a}$ after decomposition, 2a decomposes to a mass approximately equal to $\mathrm{FeS}_{2}$. The same trend is seen between the isobutyl derivatives $\mathbf{2 c}$ and 1c. TGA graphs for $\mathbf{2 b}$ and $\mathbf{2 d}$ are similar, both decomposing in several steps leaving a residual mass approximately equal to FeS, the same product to which their respective $\mathrm{Fe}(\mathrm{III})$ analogues also decompose. However, $\mathbf{2 b}$, has the lowest decomposition temperature of the four $\mathrm{Fe}(\mathrm{II})$ complexes at $180{ }^{\circ} \mathrm{C}$, while the methyl-butyl derivative (1d) has the lowest decomposition temperature of the $\mathrm{Fe}(\mathrm{III})$ dithiocarbamate species. The methyl-butyl Fe(II) derivative, 2d, decomposes at a similar temperature to $2 \mathrm{c}, 42^{\circ} \mathrm{C}$ higher than $1 \mathrm{~d}$, indicating an increased thermal stability. It should be noted that while the decompositions of the Fe(II) bis(dithiocarbamate) complexes appear as a sharp drops in percentage mass on the TGA graph, the DSC graphs show that in all cases complexes do not fall apart in one step. The latter are complicated by overlapping peaks, some of which are endothermic (as expected when a compound decomposes) and some overall exothermic. This indicates that though decomposition is rapid, it involves several steps.

For comparison we have probed the decomposition of cis$\left[\mathrm{Ru}\left(\mathrm{S}_{2} \mathrm{CNMe}_{2}\right)_{2}(\mathrm{CO})_{2}\right]^{62}$ (Fig. 3). Previous work has shown that cis-[ $\left[\mathrm{Ru}\left(\mathrm{S}_{2} \mathrm{CNR}_{2}\right)_{2}(\mathrm{CO})_{2}\right]$ decompose in solution to afford clusters

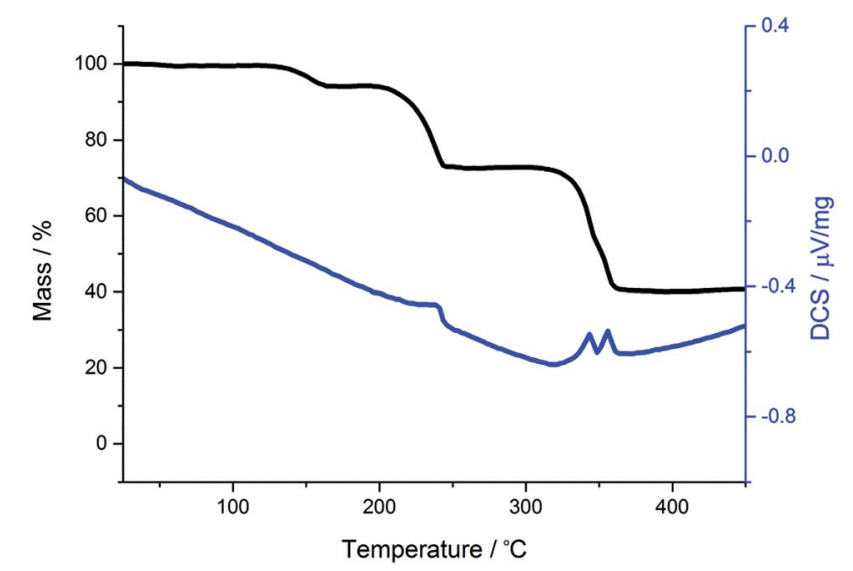

Fig. 3 TGA (black) and DSC (blue) graphs for cis$\left[\mathrm{Ru}\left(\mathrm{S}_{2} \mathrm{CNMe}_{2}\right)_{2}(\mathrm{CO})_{2}\right]$. 


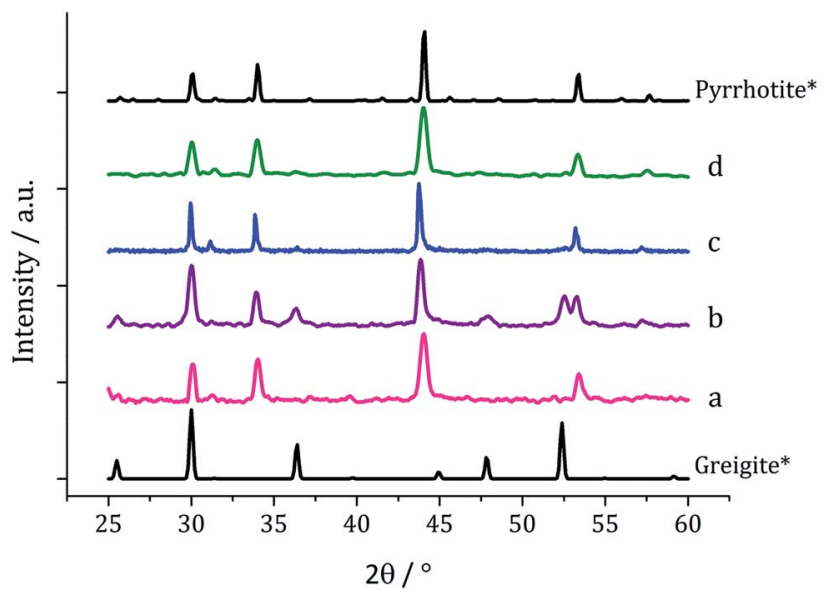

Fig. 4 PXRD patterns for nanoparticles obtained from (a) 1a, (b) 1b, (c) $1 \mathrm{c}$ and (d) 1d, with reference patterns for bulk greigite (ICDD card no. 16-0713) and pyrrhotite 4M (ICDD card no. 29-0723).

containing ligands resulting from one and two carbon-sulfur bond scission processes (formally oxidative-additions). ${ }^{62,63}$ Unlike the iron dicarbonyl complexes, decomposition occurs in a series (four) of well-defined stages. The first mass loss at $127{ }^{\circ} \mathrm{C}$ is ascribed to loss of a single carbonyl, and this is followed by a much bigger loss at $200^{\circ} \mathrm{C}$ showing now that ligand breakdown occurs before loss of the second carbonyl. The third and fourth stages occur in quick succession and are difficult to assign leaving a residual mass equivalent to $\mathrm{RuS}_{2}$ which is stable to $500{ }^{\circ} \mathrm{C}$. Thus the key difference between iron and ruthenium dicarbonyl complexes is the facile loss of both carbonyls from iron, while for ruthenium a single carbonyl is lost. This behaviour is found in solution for ruthenium, heating cis $-\left[\mathrm{Ru}(\mathrm{CO})_{2}\left(\mathrm{~S}_{2} \mathrm{CNR}_{2}\right)_{2}\right]$ leads to formation of dimeric $\left[\mathrm{Ru}(\mathrm{CO})\left(\mathrm{S}_{2} \mathrm{CNR}_{2}\right)\left(\mu-\mathrm{S}_{2} \mathrm{CNR}_{2}\right)\right]_{2}{ }^{64}$

\section{(iii) Decomposition of $\left[\mathrm{Fe}\left(\mathrm{S}_{2} \mathrm{CNR}_{2}\right)_{3}\right]$}

Decompositions were carried out in oleylamine $e^{42}$ at $230{ }^{\circ} \mathrm{C}$ using the 'heat-up' method. Pyrrhotite has been suggested to be thermodynamically more stable than greigite under the conditions employed in this study, and it is also more readily formed upon decomposing certain SSPs. ${ }^{53}$ We initially probed how varying alkyl substituents in 1a-d affects the product. Each gave a dark brown solution upon dissolution in oleylamine, but unexpectedly at $75{ }^{\circ} \mathrm{C}$ all turned pale yellow and clear, then at $80^{\circ} \mathrm{C}$ they quickly went black. And after $1 \mathrm{~h}$ nanoparticles were isolated as black powders. Powder X-ray diffraction (PXRD) analysis revealed that pure pyrrhotite $\left(\mathrm{Fe}_{7} \mathrm{~S}_{8}\right.$, ICDD card no. 0290723) was formed, except with $\mathbf{1 b}$ where a small amount of greigite (ICDD card no. 016-0713) was also observed (Fig. 4). O'Brien has previously found that decomposition of $\left[\mathrm{Fe}\left(\mathrm{S}_{2}-\right.\right.$ $\left.\left.\mathrm{CNRR}^{\prime}\right)_{3}\right]$ formed predominantly greigite, but showed peaks for pyrrhotite at higher temperatures $\left(230\right.$ and $\left.300{ }^{\circ} \mathrm{C}\right) .{ }^{53}$ The lower SSP concentrations used in this work could be a factor as to why the thermally more stable pyrrhotite was predominantly formed.

Average particle size (Fig. 5) decreased as the size of the dithiocarbamate substituents increased; 1c (av. $84 \mathrm{~nm}$ ) containing the large ${ }^{\mathrm{i}} \mathrm{Bu}$ substituents. This might suggests that precursors with shorter alkyl chains take longer to decompose, therefore forming larger nanoparticles (less nucleation sites and more growth) and this is supported by the work of O'Brien who found that $\left[\mathrm{Fe}\left(\mathrm{S}_{2} \mathrm{CNR}_{2}\right)_{3}\right]$ complexes with shorter alkyl chains required higher temperatures to decompose in oleylamine. ${ }^{53}$ High Resolution Transmission Electron Microscopy (HRTEM) of the particles produced from 1c shows spacings of $2.67 \AA$, consistent with the [004] lattice plane of pyrrhotite- $4 \mathrm{M}$ (2.64 $\AA$, ICDD card no. 29-0723).

We next probed how decomposition of $\left[\mathrm{Fe}\left(\mathrm{S}_{2} \mathrm{CN}^{\mathrm{i}} \mathrm{Bu}_{2}\right)_{3}\right](\mathbf{1 c})$ was affected by temperature. Solutions $(5 \mathrm{mM})$ in oleylamine $(20$ $\mathrm{mL}$ ) were heated for $1 \mathrm{~h}$ at $150,180,260$ and $280^{\circ} \mathrm{C}$ respectively and compared via PXRD (Fig. 6) to the sample at $230^{\circ} \mathrm{C}$. Those prepared below $230^{\circ} \mathrm{C}$ were mostly amorphous, except for some small broad peaks for greigite and pyrrhotite. This is in accordance with $\mathrm{GaO}^{41}$ and $\mathrm{O}^{\prime} \mathrm{Brien}^{53}$ who both obtained amorphous materials at lower temperatures, with greigite forming at intermediate temperatures, while pyrrhotite was favoured at higher temperatures. Samples prepared at 150 and $180^{\circ} \mathrm{C}$ were
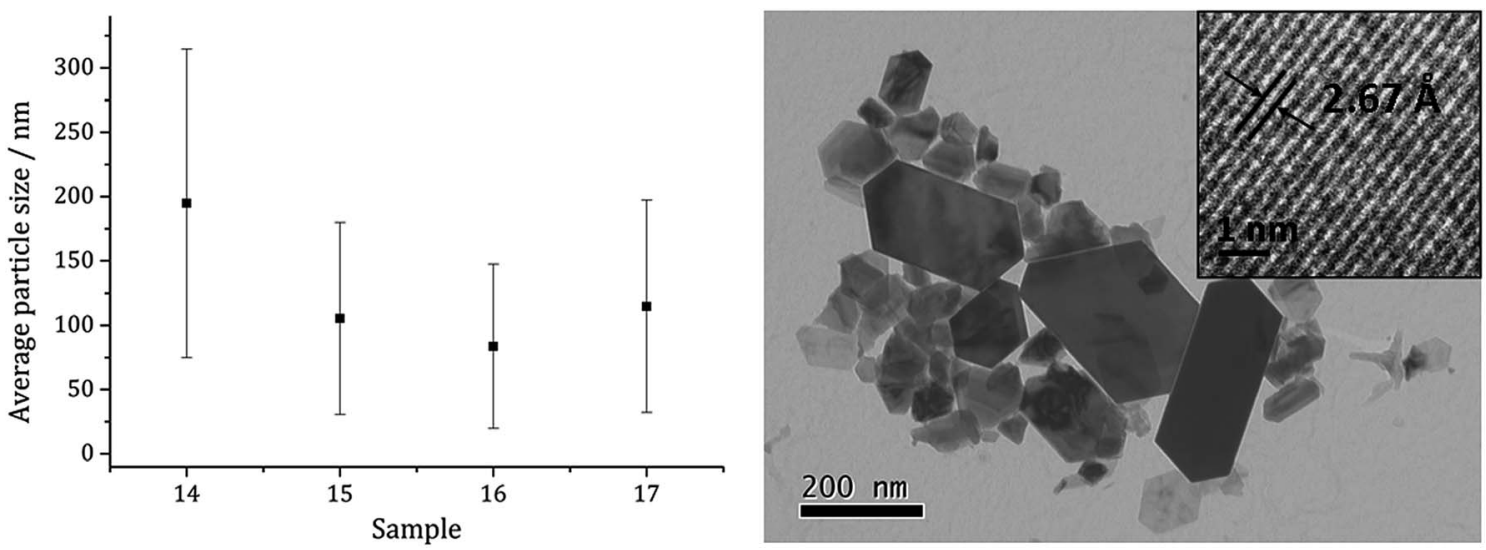

Fig. 5 Average particle size (one SD above and below) of samples prepared from 1a-d (left) and TEM image of sample prepared from 1c with HRTEM inset (right). 


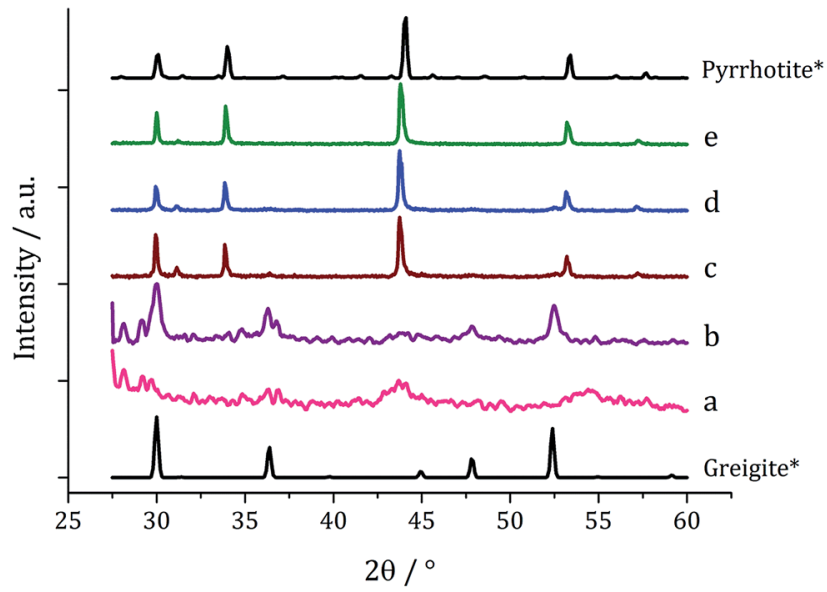

Fig. 6 PXRD patterns for samples prepared from $1 \mathrm{c}$ at (a) $150{ }^{\circ} \mathrm{C}$, (b) $180{ }^{\circ} \mathrm{C}$, (c) $230{ }^{\circ} \mathrm{C}$, (d) $260^{\circ} \mathrm{C}$ and (e) $280{ }^{\circ} \mathrm{C}$, with reference patterns for bulk greigite (ICDD card no. 16-0713) and pyrrhotite 4M (ICDD card no. 29-0723).

unstable in air and oxidised to orange-brown powders after 2-3 days suggesting incomplete decomposition of the SSP, whereas all the other samples remained as black powders several months post synthesis.

TEM (Fig. 7) clearly shows the progression from amorphous materials at low temperatures to crystalline material at higher temperature, while nanoparticle shape does not change significantly, being consistent with previous findings. ${ }^{41,53}$ Average particle size decreases as temperature is increased (Fig. 7f) and this could be an effect of the decomposition rate.

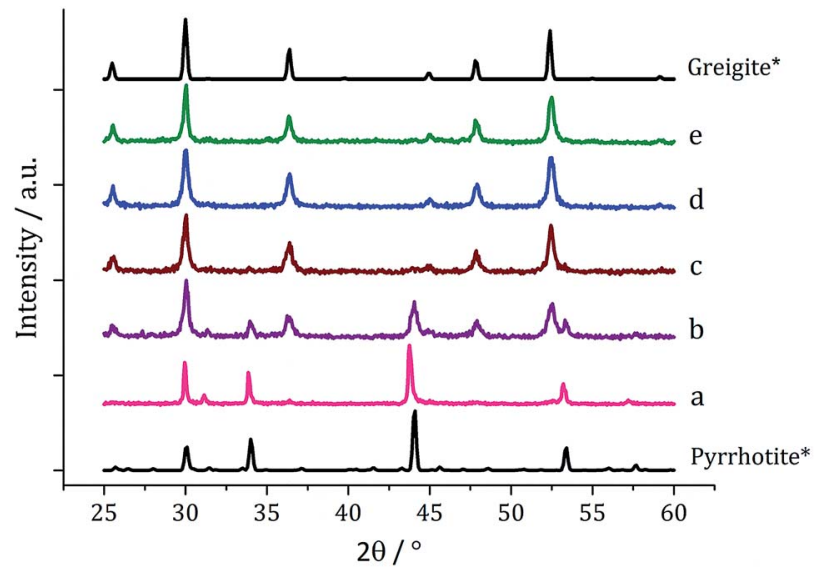

Fig. 8 PXRD patterns for samples prepared from 1c at (a) 5, (b) 10, (c) 20, (d) 40 and (e) $50 \mathrm{mM}$ concentration, with reference patterns for bulk pyrrhotite 4M (ICDD card no. 29-0723) and greigite (ICDD card no. 16-0713).

Since at lower temperatures some greigite was formed, in order to access pure greigite in a crystalline form, further decomposition studies were carried out at $230{ }^{\circ} \mathrm{C}$. The concentration of 1c was varied (10-50 mM, in $20 \mathrm{~mL}$ oleylamine for $1 \mathrm{~h}$ at $230{ }^{\circ} \mathrm{C}$ ) and the resulting nanomaterials compared with the sample prepared using $5 \mathrm{mM}$. PXRD analysis shows a progression from pyrrhotite to greigite with increasing concentration (Fig. 8). Formation of pure greigite was possible at $40-50 \mathrm{mM}$ precursor concentrations, consistent with the work of Gao and O'Brien. ${ }^{41,53}$ A HRTEM image of the $40 \mathrm{mM}$ sample (Fig. 9 right), shows $d$-spacings of 2.55 and $2.97 \AA$,
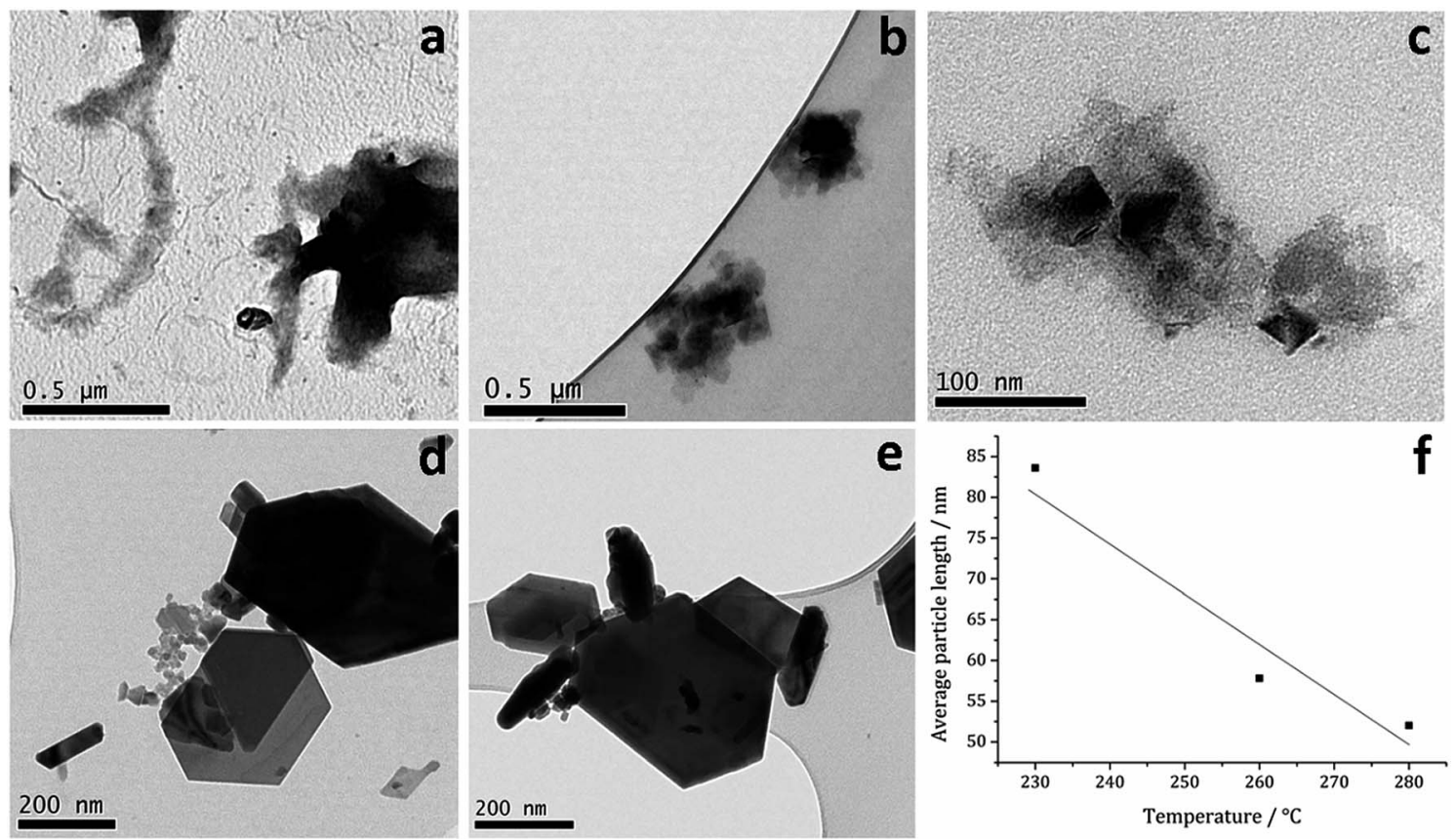

Fig. 7 TEM images of samples prepared from 1c at (a) 150, (b) 180, (c) 230, (d) 260 and (e) $280{ }^{\circ} \mathrm{C}$, (f) graph of average particle length against temperature of decomposition. 


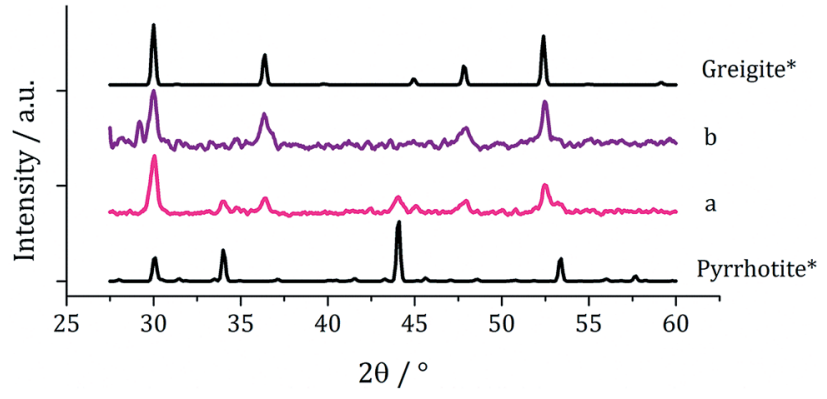

Fig. 9 PXRD patterns for samples produced from (a) 2a and (b) 2a with 1a, with reference patterns for bulk pyrrhotite 4M (ICDD card no. 290723) and greigite (ICDD card no. 16-0713).

consistent with the [400] and [311] lattice planes of greigite (2.47 and $2.98 \AA$ respectively, ICDD card no. 16-0713). O'Brien has previously studied decomposition of $\left[\mathrm{Fe}\left\{\mathrm{SON}\left(\mathrm{CN}^{\mathrm{i}} \mathrm{Pr}_{2}\right)_{2}\right\}_{3}\right]$ at varying concentrations. ${ }^{65}$ At $5-10 \mathrm{mM}$ pyrrhotite was formed, but increasing to $20 \mathrm{mM}$ produced an amorphous material, suggesting that concentration plays a role in the crystallinity of the resultant material. The trend observed in the current study, suggests concentration variations may allow access to metastable phases such that at higher concentration the metastable phase greigite is formed.

(iv) Decomposition of Fe(II) dithiocarbamate SSPs and Fe(III)Fe(II) mixtures

The work described above shows that it is possible to produce greigite (which contains both $\mathrm{Fe}(\mathrm{II})$ and $\mathrm{Fe}(\mathrm{III})$ centres) from a single $\mathrm{Fe}(\mathrm{III})$ SSP but only within a small range of SSP concentration and decomposition temperature. We thus sought to use $\mathrm{Fe}(\mathrm{II}) \mathrm{SSP}$ to potentially widen the range of conditions under which greigite nanomaterials could be produced. We first explored the decomposition of cis-[ $\left.\mathrm{Fe}\left(\mathrm{S}_{2} \mathrm{CNMe}_{2}\right)_{2}(\mathrm{CO})_{2}\right](2 \mathrm{a})$ in oleylamine at $230{ }^{\circ} \mathrm{C}$ for $1 \mathrm{~h}$. The complex is only sparingly soluble at room temperature but even upon warming to $35^{\circ} \mathrm{C}$ it had fully dissolved to give a dark red-brown solution. The resulting nanoparticles were isolated after cooling the mixture by addition of excess methanol and separation by centrifugation. For comparison a similar decomposition of a $1: 1$ mixture of $2 \mathrm{a}(2.5 \mathrm{mM})$ and $\left[\mathrm{Fe}\left(\mathrm{S}_{2} \mathrm{CNMe}_{2}\right)_{3}\right](\mathbf{1 a}, 2.5 \mathrm{mM})$ was carried out, giving a black powder. In both cases, PXRD analysis (Fig. 9) revealed a mixture of greigite and pyrrhotite, although disappointingly the low quality of the patterns indicate that little crystalline material was produced.

Decomposition of a 1a/2a mixture did not produce greigite. This is surprising as even at $240{ }^{\circ} \mathrm{C}$ Gao obtained a mixture of greigite and pyrrhotite from $\left[\mathrm{Fe}\left(\mathrm{S}_{2} \mathrm{CNEt}_{2}\right)_{3}\right](\mathbf{1 b})^{41}$ and O'Brien also generated a mixture greigite-pyrrhotite at $230{ }^{\circ} \mathrm{C} .{ }^{53}$ TEM (Fig. 10) shows hexagonal nanocrystals, similar in appearance to the pyrrhotite synthesised by Gao, ${ }^{41} \mathrm{Xu}-\mathrm{Wang}^{42}$ and O'Brien,,$^{53}$ with a particle diameter range of $20-320 \mathrm{~nm}$, being lower than that obtained from $2 \mathrm{a}$ alone.

\section{(v) Decomposition of $\left[\mathrm{Fe}\left(\mathrm{S}_{2} \mathrm{CNR}_{2}\right)_{3}\right]$ with added thiuram disulfide}

As briefly communicated ${ }^{66}$ we followed structural changes upon heating $\left[\mathrm{Fe}\left(\mathrm{S}_{2} \mathrm{CN}^{\mathrm{i}} \mathrm{Bu}_{2}\right)_{3}\right]$ (1c) in oleylamine by in situ X-ray absorption spectroscopy (XAS) (discussed in detail later). Pertinent here is the observation that at $60^{\circ} \mathrm{C}$ reduction of $\mathrm{Fe}(\mathrm{III})$ to Fe(II) occurs via an intramolecular electron-transfer, associated with concurrent oxidation of dithiocarbamate to thiuram disulfide (Scheme 2). Thus Fe(III) SSPs actually convert to formation of $\mathrm{Fe}(\mathrm{II})$ species in the decomposition media. Since thiuram disulfides are oxidising agents, adding to low valent metal centres as two dithiocarbamate ligands via an oxidativeaddition process, ${ }^{67-72}$ we considered that an equilibrium was operating. $\mathrm{Hu}$ and Zhang previously considered the role of thiuram disulfides in the solvothermal synthesis of $\mathrm{CdS}^{73}$ and we have also recently shown that addition of tetra-isobutylthiuram disulfide (3) to the oleylamine solutions of $\left[\mathrm{Ni}\left(\mathrm{S}_{2} \mathrm{CN}^{\mathrm{i}} \mathrm{Bu}_{2}\right)_{2}\right]$ can have a significant effect on the nanomaterials generated. ${ }^{74}$

One equivalent of 3 was added to $1 \mathrm{c}(5 \mathrm{mM})$ and decomposed in oleylamine at $230^{\circ} \mathrm{C}$ for $1 \mathrm{~h}$. The materials produced gave off a sulfurous smell, indicating the presence of excess sulfur. The resulting black powder was analysed by PXRD and found to be a mixture of pyrrhotite and greigite (Fig. 11a). Notably, addition of 3 has promoted the stabilisation of the greigite phase. In an
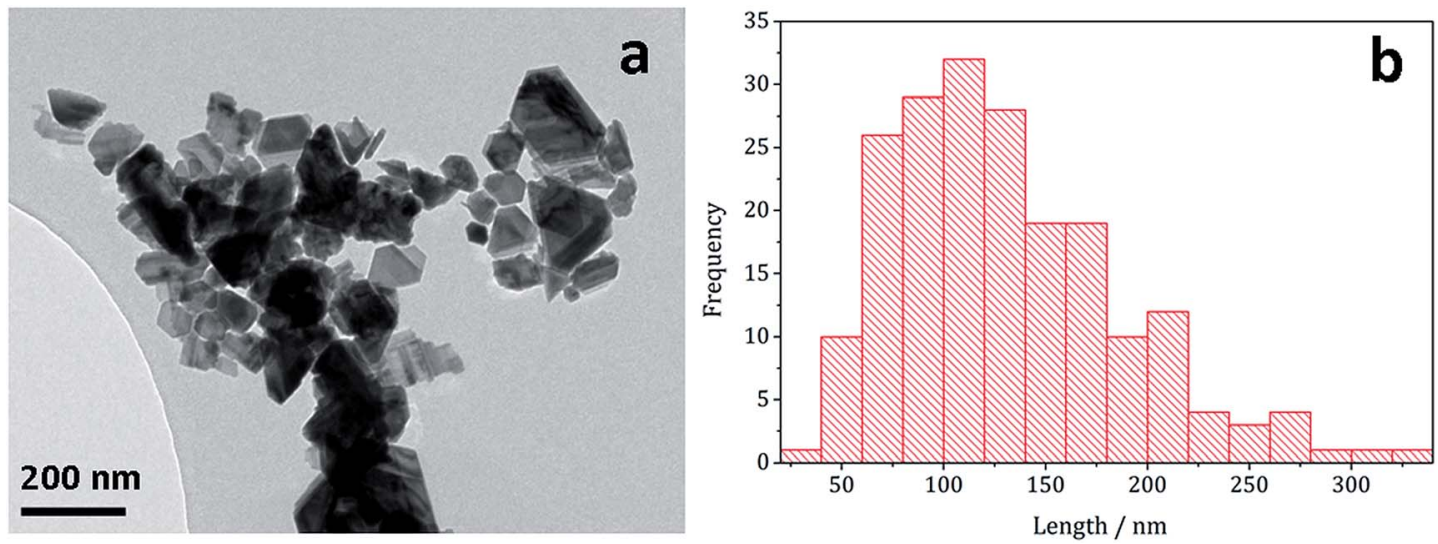

Fig. 10 (a) TEM image and (b) histogram of particle length for pyrrhotite particles obtained from decomposition of 1a/2a mixture. 


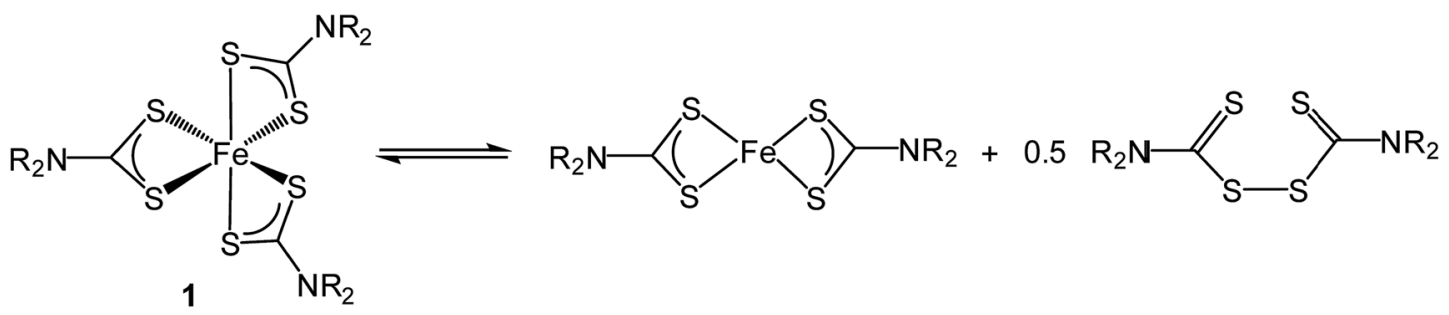

Scheme 2 Thermally-induced reduction of $\left[\mathrm{Fe}\left(\mathrm{S}_{2} \mathrm{CNR}_{2}\right)_{3}\right]$ (1) to give $\left[\mathrm{Fe}\left(\mathrm{S}_{2} \mathrm{CNR}_{2}\right)_{2}\right]$ and thiuram disulfide.

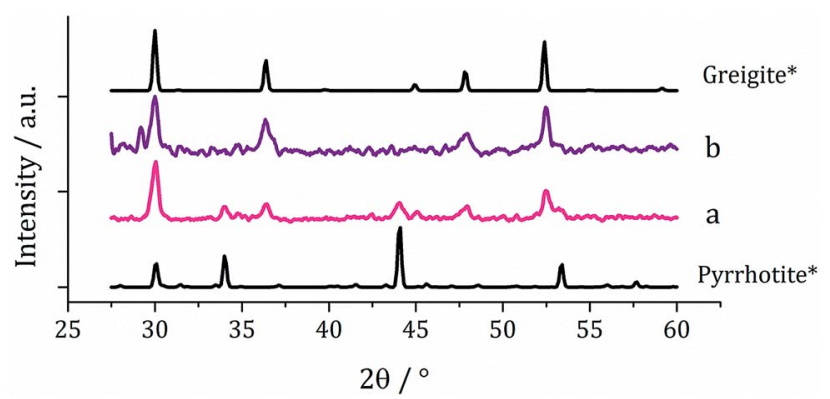

Fig. 11 PXRD patterns for samples prepared from 1c (5 mM) with (a) one equivalent and (b) two equivalents of 3 , with reference patterns for bulk pyrrhotite 4M (ICDD card no. 29-0723) and greigite (ICDD card no. 16-0713).

attempt to form pure greigite, the decomposition was repeated with two equivalents of $\mathbf{3}$, and analysis of the resulting particles showed that indeed that pure greigite was formed (Fig. 11b).

Based on this result, 1c $(5 \mathrm{mM})$ and $3(10 \mathrm{mM})$ were decomposed in oleylamine for $1 \mathrm{~h}$ at different temperatures (Fig. 12). At lower temperatures only amorphous materials resulted, but at intermediate temperatures greigite was produced, and with high purity at $260{ }^{\circ} \mathrm{C}$. Above $260{ }^{\circ} \mathrm{C}$, pyrrhotite becomes prevalent, consistent with this being the thermodynamic product. In comparison to decomposition of

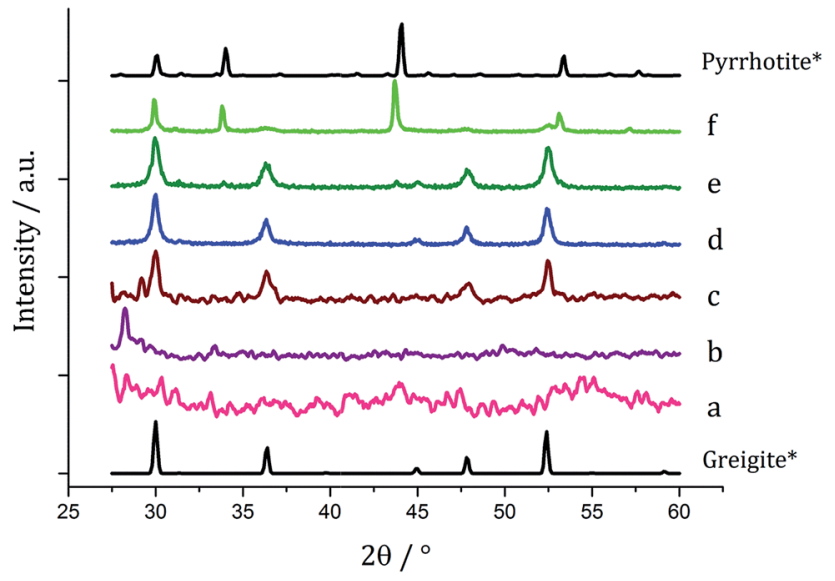

Fig. 12 PXRD patterns for samples prepared from $1 \mathrm{c}(5 \mathrm{mM})$ and 3 (10 $\mathrm{mM}$ ) at (a) 150, (b) 180, (c) 230 , (d) 260 , (e) 280 and (f) $300{ }^{\circ} \mathrm{C}$, with reference patterns for bulk greigite (ICDD card no. 16-0713) and pyrrhotite 4M (ICDD card no. 29-0723). the SSPs alone, pure crystalline materials can be accessed due to the greater stability of greigite in the presence of 3 .

Fig. 13a shows a graph of the average particle size for samples prepared at $150-300{ }^{\circ} \mathrm{C}$, from which it can be seen that the size decreases slightly with increasing temperature, consistent with the trend seen in the samples prepared without added thiuram disulfide. A TEM image (Fig. 13b) of the material produced at $260{ }^{\circ} \mathrm{C}$ shows that while particle morphology is similar to the greigite nanoparticles prepared in the absence of 3 , the average particle size of the former is smaller (34 $\mathrm{nm}$ as compared to $55 \mathrm{~nm}$ respectively). HRTEM of the $260{ }^{\circ} \mathrm{C}$ sample (Fig. 13b inset) shows spacings of $5.95 \AA$, consistent with the [111] lattice plane of greigite, and this temperature was chosen to develop concentration studies as it is the lowest temperature where pure crystalline material is produced.

When 1c and 3 (in a $1: 2$ ratio) were decomposed at $260{ }^{\circ} \mathrm{C}$ (10:20, $20: 40,40: 80$ and $50: 100 \mathrm{mM})$ the black powders formed in all cases were greigite (see PXRD analysis in Fig. 14), although at the higher concentrations there were also anomalous low angle peaks believed to be due to excess sulfur. In order to confirm this, 3 alone was decomposed ( $80 \mathrm{mM}$ ) and the PXRD pattern of the resulting brown powder was a good match to the anomalous peaks seen previously.

The average particle size does not vary significantly with increasing concentration (Fig. 15) suggesting that 3 may be acting also as a capping/stabilising agent, halting particle growth at $c a .40 \mathrm{~nm}$. An implication is that greigite can be consistently synthesised at reasonably high precursor concentrations, allowing doping of other metals into the greigite structure, potentially important for future studies.

\section{(vi) In situ XAS studies and plausible decomposition mechanism}

In recent work we studied the decomposition of $\left[\mathrm{Ni}\left(\mathrm{S}_{2} \mathrm{CN}^{\mathrm{i}} \mathrm{Bu}_{2}\right)_{2}\right]$ in hexylamine $\left(\mathrm{HexNH}_{2}\right)$ by in situ XAS. ${ }^{75}$ Key findings were; (i) the amine coordinated to the metal centre at low temperatures to afford octahedral complexes $\left[\mathrm{Ni}\left(\mathrm{NH}_{2} \mathrm{Hex}\right)_{2}\left(\mathrm{~S}_{2} \mathrm{CN}^{\mathrm{i}} \mathrm{Bu}_{2}\right)_{2}\right]$; (ii) as the temperature was raised the primary amine displaced the ${ }^{\mathrm{i}} \mathrm{Bu}_{2} \mathrm{NH}$ via amide-exchange resulting in formation of $\left[\mathrm{Ni}\left(\mathrm{S}_{2}-\right.\right.$ CNHHex $\left.)_{2}\right]$; (iii) $\left[\mathrm{Ni}\left(\mathrm{S}_{2} \mathrm{CNHHex}\right)_{2}\right]$ decomposes at low temperatures via deprotonation (accelerated by base) with extrusion of HexNCS. We were also able to support these experimental observations with DFT studies allowing a good overall view of the likely decomposition pathway(s) to be developed. Due to the high-low spin crossover nature of $\left[\mathrm{Fe}\left(\mathrm{S}_{2} \mathrm{CNR}_{2}\right)_{3}\right]$, related 

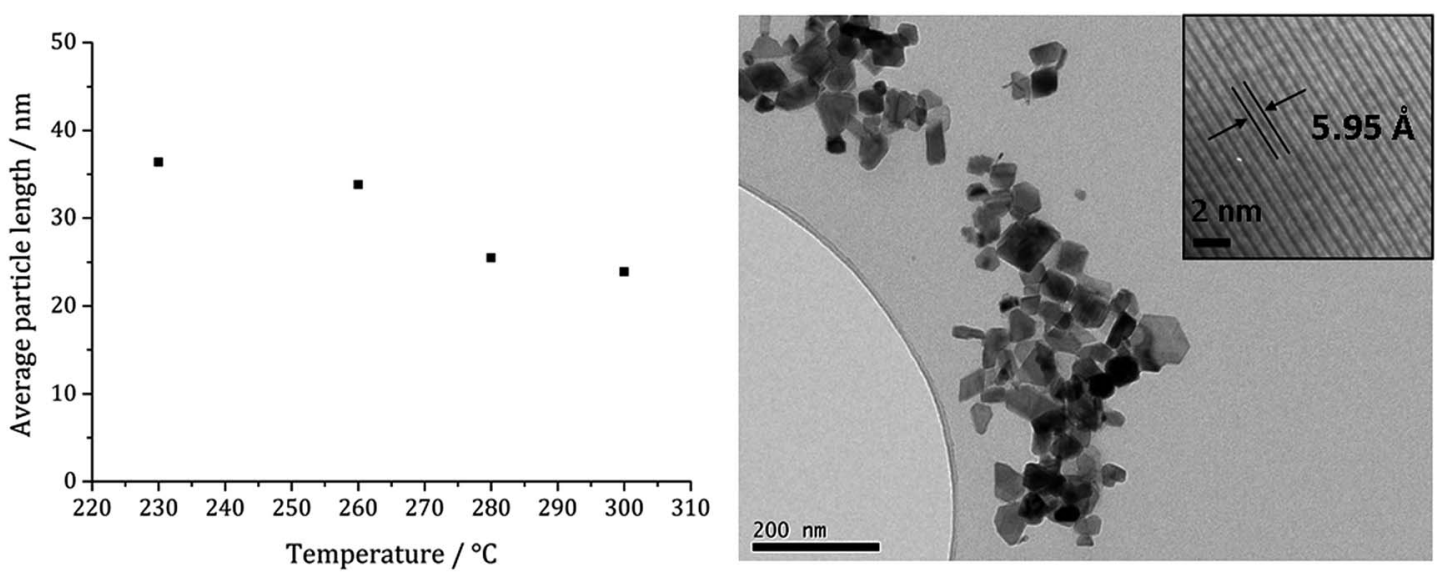

Fig. 13 Graph showing the average particle length against temperature of decomposition for precursors $1 \mathrm{c}$ (5 mM) and 3 (10 mM) (left). TEM image of sample prepared at $260^{\circ} \mathrm{C}$ with HRTEM inset (right).

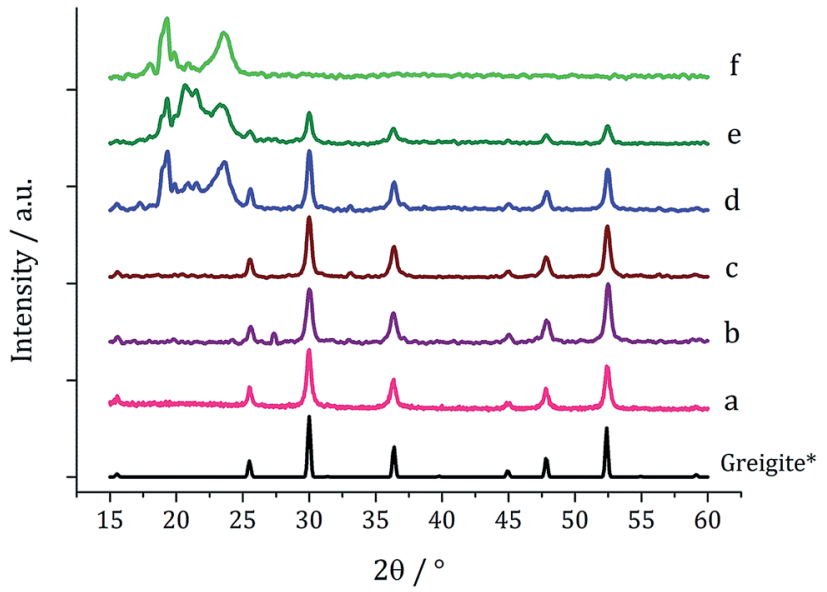

Fig. 14 PXRD patterns for samples prepared from $1 \mathrm{c}$ and 3 at concentrations of (a) 5 and $10 \mathrm{mM}$, (b) 10 and $20 \mathrm{mM}$, (c) 20 and $40 \mathrm{mM}$, (d) 40 and $80 \mathrm{mM}$, and (e) $50 \mathrm{mM}$ and $0.5 \mathrm{M}$, (f) 6 decomposed alone at $80 \mathrm{mM}$, with reference pattern for bulk greigite (ICDD card no. 16-0713).

theoretical studies would be complicated and thus we do not consider them here, but note an expectation that high spin complexes would be far more labile than low-spin isomers.

We first considered the molecular structure and thermal stability of $\left[\mathrm{Fe}\left(\mathrm{S}_{2} \mathrm{CN}^{\mathrm{i}} \mathrm{Bu}_{2}\right)_{3}\right](\mathbf{1 c})$ in the solid-state and in the noncoordinating dodecane. XANES spectra show (Fig. 16a) that the molecular structure is essentially identical under both conditions confirming that the bidentate nature of the dithiocarbamate is maintained upon dissolution in dodecane. Thus EXAFS fitting for $1 \mathbf{c}$ in the solid-state correspond well with the single crystal X-ray diffraction data, ${ }^{76}$ showing six $\mathrm{Fe}-\mathrm{S}$ distances of $2.30 \AA$ A. In contrast, dissolution in oleylamine afforded a quite different XANES spectrum; white line intensity at $c a .7124 \mathrm{eV}$ (labelled B) being far more prominent that in the solid-state or dodecane, while the shoulder at $c a .7119 \mathrm{eV}$ (labelled A) in the latter two spectra associated with the p-orbital contribution of sulfur to the $4 \mathrm{~s}$ orbital of iron is much reduced in oleylamine.
This provides strong evidence that the local octahedral tris(dithiocarbamate) structure is not maintained in oleylamine. Modelling of $1 \mathrm{c}$ in oleylamine strongly suggests that, upon coordination of the amine, the dithiocarbamate ligands become monodentate, and best fit supports a model with a fivecoordinate trigonal bipyramidal iron centre ligated by two amines in the axial sites (Fe-N $1.89 \AA$ A ) with three monodentate dithiocarbamate ligands (Fe-S 2.21 and $3.08 \AA$ A occupying the basal positions. ${ }^{66}$ Thus upon dissolution in oleylamine $1 \mathrm{c}$ is actually best considered as $\left[\mathrm{Fe}\left(\kappa_{1}-\mathrm{S}_{2} \mathrm{CN}^{\mathrm{i}} \mathrm{Bu}_{2}\right)_{3}\left(\mathrm{RNH}_{2}\right)_{2}\right](\mathrm{R}=$ oleyl) (Scheme 3). Amine binding might also explain the significantly enhanced solubility of $\left[\mathrm{Fe}\left(\mathrm{S}_{2} \mathrm{CNMe}_{2}\right)_{3}\right]$ in oleylamine above $35^{\circ} \mathrm{C}$.

In situ XAS studies were carried out on the decomposition of $1 \mathrm{c}$ in oleylamine. For these experiments we attempted to replicate the laboratory conditions as best we could and we used the same concentrations of all reagents. Nevertheless, the cell design does not allow for a mixing mechanism, and thus the potential for larger nanomaterials to be deposited at the bottom of the cell cannot be discounted. Further the cell is closed and thus venting of generated gases cannot occur, while heat loss across the cell in this geometry is inevitable since there is a small cell body at the centre which faces ambient conditions. To counter this we performed temperature calibrations prior to experiments using a secondary thermocouple accessed through a small hole in the reaction chamber, thus we believe that we had a good estimate of temperature in the reaction chamber at all times.

Little change occurred in the XANES spectra up to $c a .70{ }^{\circ} \mathrm{C}$, suggesting that the amine-adduct remains intact. Above $70{ }^{\circ} \mathrm{C}$ an edge shift was apparent (Fig. 16b) being indicative of reduction of $\mathrm{Fe}(\mathrm{III})$ to $\mathrm{Fe}$ (II). EXAFS analysis supports an octahedral $\mathrm{Fe}(\mathrm{II})$ centre ligated by two chelating dithiocarbamate ligands and two amines; $\left[\mathrm{Fe}\left(\mathrm{S}_{2} \mathrm{CN}^{\mathrm{i}} \mathrm{Bu}_{2}\right)_{2}\left(\mathrm{RNH}_{2}\right)_{2}\right]$ (Scheme 3). This fits well with the decomposition studies, where between $c a$. $75{ }^{\circ} \mathrm{C}$ the intense brown solution become pale yellow very suddenly; we associate this change with reduction of the iron centre. Previous work on related xanthate complexes, 

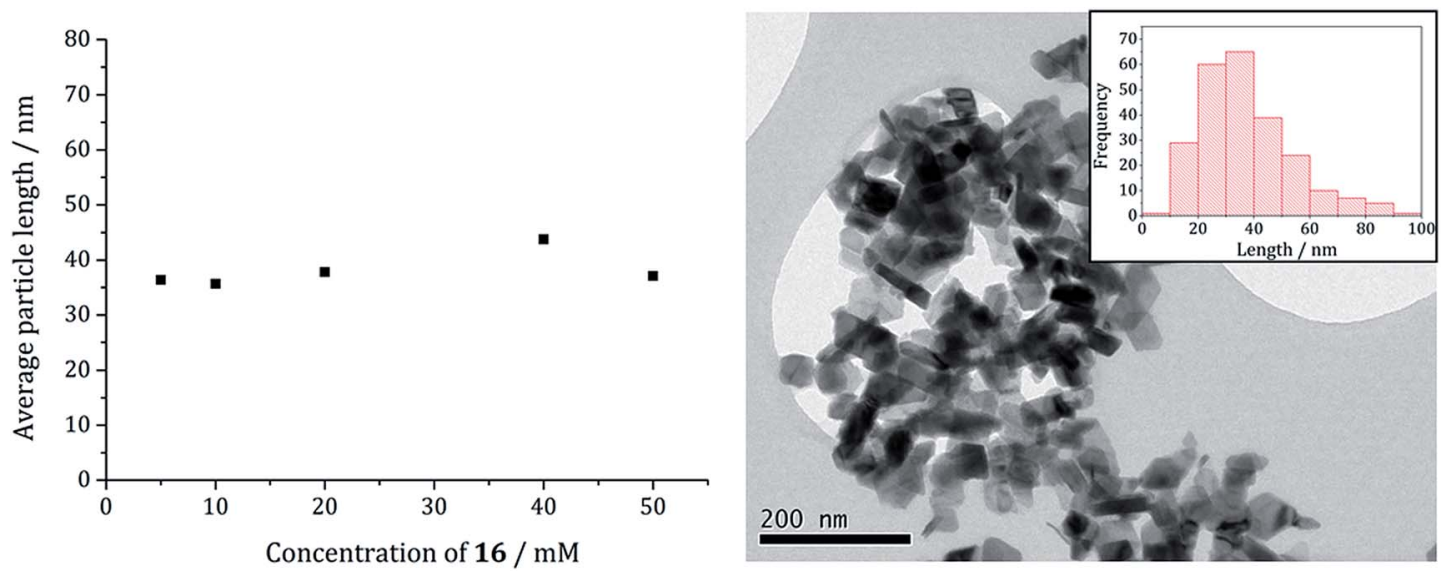

Fig. 15 Average particle length of samples prepared from $1 \mathrm{c}$ and 3 at various concentrations (in a $1: 2$ ratio) (left). TEM image of greigite prepared from $2 \mathrm{~d}(20 \mathrm{mM})$ and $1 \mathrm{a}(40 \mathrm{mM})$ with particle length histogram inset (right).

$\left[\mathrm{Fe}\left(\mathrm{S}_{2} \mathrm{COR}\right)_{3}\right]$, showed a similar $\mathrm{Fe}(\mathrm{III})$ to $\mathrm{Fe}(\mathrm{II})$ reduction upon addition of pyridine, the products being $\left[\mathrm{Fe}\left(\mathrm{S}_{2} \mathrm{COR}\right)_{2}(\mathrm{py})_{2}\right]$ and $\left(\mathrm{ROCS}_{2}\right)_{2}{ }^{.77}$ Reduction of $\mathrm{Fe}(\mathrm{III})$ to Fe(II) involves intramolecular electron-transfer with concomitant oxidation of dithiocarbamate to thiuram disulfide 3 . While we have not carried out XAS studies on iron(II) dicarbonyl complexes, 2, a similar scheme may be invoked; that is thermal loss of both carbonyls generating square-planar $\left[\mathrm{Fe}\left(\mathrm{S}_{2} \mathrm{CNR}_{2}\right)_{2}\right]$ in situ which rapidly coordinates amine to afford the same intermediate. Thus Fe(II) and $\mathrm{Fe}(\mathrm{III})$ SSPs are likely generating the same molecular precursors in the amine solution.

Between 67 and $125{ }^{\circ} \mathrm{C}$ XAS data was lost due to the severe inhomogeneity of the reaction mixture; showing that it is between these temperatures that nanoparticle formation occurs. Consequently we cannot confidently comment directly on whether amide-exchange seen previously at a $\mathrm{Ni}$ (II) centre, ${ }^{75}$ whereby $\left[\mathrm{Ni}\left(\mathrm{S}_{2} \mathrm{CN}^{\mathrm{i}} \mathrm{Bu}_{2}\right)_{2}\right]$ is converted into $\left.\left[\mathrm{Ni}\left(\mathrm{S}_{2} \mathrm{CNHR}\right)_{2}\right)\right]$ occurs at the $\mathrm{Fe}(\mathrm{II})$ centre. However, we would expect that changing from a square-planar $\mathrm{Ni}$ (II) to $\mathrm{Fe}(\mathrm{II})$ centre would not significantly alter the reactivity of the bound ligands (we realise that a $\mathrm{d} 8$ square planar geometry for $\mathrm{Ni}(\mathrm{II})$ is probable, while for d6 Fe(II) a low spin octahedral arrangement is attractive), and thus we propose a related exchange occurs rapidly after the electron-transfer to afford $\left[\mathrm{Fe}\left(\mathrm{RNH}_{2}\right)_{2}\left(\mathrm{~S}_{2} \mathrm{CNHR}\right)_{2}\right]$ (Scheme 3). The rapid nature of the nanoparticle formation above $60{ }^{\circ} \mathrm{C}$ strongly suggests that amide-exchange is fast at the $\mathrm{Fe}(\mathrm{II})$ centre.

We have previously shown that nickel complexes with primary amine backbones decompose at much lower temperatures than those with secondary amines due to the basemediated deprotonation of the backbone proton(s) and subsequent extrusion of organic isothiocyanate. ${ }^{75}$ Thus we would expect $\left[\mathrm{Fe}\left(\mathrm{RNH}_{2}\right)_{2}\left(\mathrm{~S}_{2} \mathrm{CNHR}\right)_{2}\right]$ to rapidly extrude oleylisocyanate (RNCS) (two equivalents shown) to afford a small molecular precursor that can nucleate to give the observed iron sulfide nanomaterials (Scheme 3).

This then leads us to return to consider how addition of thiuram disulfide 3 affects the decomposition mechanism; allowing greigite to be formed under conditions where in its absence pyrrhotite formation is favoured. As discussed earlier, the most obvious point of entry of thiuram disulfide is at the $\mathrm{Fe}(\mathrm{III})-\mathrm{Fe}$ (II) redox transformation, as clearly addition should move the equilibrium towards $\mathrm{Fe}(\mathrm{III})$. Especially if reduction is rate-limiting then addition of $\mathbf{3}$ should have a significant effect. The second place it can be potentially important is later in the transformation as a sulfur source. Thus purported "FeS(OA)" fragments are anticipated to be highly reactive and may be able
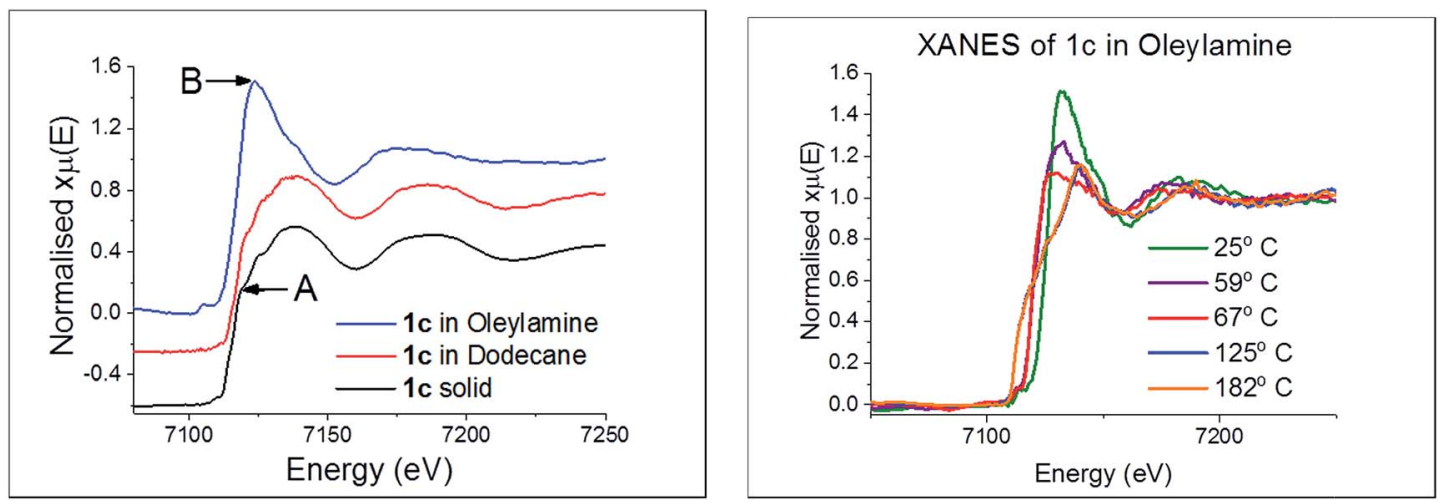

Fig. 16 (a) XANES spectra of $1 \mathrm{c}$ in various forms, (b) in oleylamine at various temperatures. 


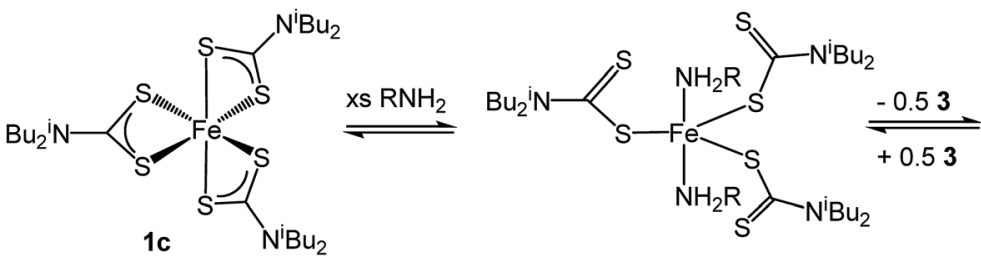

Scheme 3

$$
\mathrm{R}=\text { oleyl }
$$

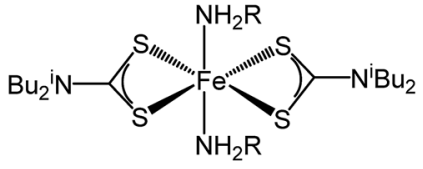

xs $\mathrm{RNH}_{2} \downarrow-2{ }^{\mathrm{i}} \mathrm{Bu}_{2} \mathrm{NH}$

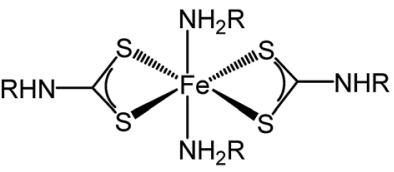

Scheme 3 Proposed route for the conversion of $\left[\mathrm{Fe}\left(\mathrm{S}_{2} \mathrm{CN}^{i} \mathrm{Bu}_{2}\right)_{3}\right](1 \mathrm{c})$ into iron sulfide nanomaterials upon heating in oleylamine $\left(\mathrm{RNH}_{2}\right)$.

to abstract sulfur from 3 to give the corresponding thiuram monosulfide. This would also result in oxidation of the metal centre and thus account for both the increased sulfur content and overall metal oxidation state seen in greigite $\left(\mathrm{Fe}_{3} \mathrm{~S}_{4}\right)$ versus pyrrhotite $\left(\mathrm{Fe}_{1-x} \mathrm{~S}\right)$.

\section{Summary and conclusions}

Solvothermal decomposition of iron(II) and iron(III) dithiocarbamate SSPs has been thoroughly and systematically investigated by changing a range of reaction variables in order to probe the changes to materials formed. Iron(II) dithiocarbamate SSPs were not required to produce iron sulfide nanoparticles containing $\mathrm{Fe}(\mathrm{II})$ ions since they can be generated upon reduction of $\mathrm{Fe}(\mathrm{III})$ species. This process is relatively fast as shown when the decomposition of $\left[\mathrm{Fe}\left(\mathrm{S}_{2} \mathrm{CNBu}_{2}{ }_{2}\right)_{3}\right](\mathbf{1 c})$ was halted immediately upon reaching the decomposition temperature pure greigite resulted. However, the greigite formed is a metastable phase and, if enough energy is supplied, pyrrhotite will forms. Greigite formation can be promoted by reducing the decomposition time, lowering the temperature and increasing the precursor concentration. All these factors decrease the amount of energy transferred to each precursor unit and so prevent the formation of the more thermodynamically favoured phase (pyrrhotite). In addition, precursor choice can have an effect. Thus $\left[\mathrm{Fe}\left(\mathrm{S}_{2}-\right.\right.$ $\left.\left.\mathrm{CNEt}_{2}\right)_{3}\right](\mathbf{1 b})$ showed a greater propensity towards the formation of greigite, which may be due to a different decomposition mechanism being at work, or to the formation of a by-product that stabilises the greigite phase.

Addition of thiuram disulfide (3) to the decomposition system had a significant effect, such that at high concentrations of 3 greigite could be prepared at higher temperatures and lower concentrations of 1c. Reasons for this difference are not clear but could relate to relative ratios of $\mathrm{Fe}(\mathrm{III})$ and $\mathrm{Fe}(\mathrm{II})$ species in the decomposition mixture which affects the overall decomposition mechanism. Decomposition of the $\mathrm{Fe}(\mathrm{II})$ precursor 2a produces pure pyrrhotite $\left(\mathrm{Fe}_{7} \mathrm{~S}_{8}\right)$ nanoparticles with similar morphology to those previously synthesised from other iron(II) dithiocarbamate precursors. The addition of an Fe(III) source 1a, did not lead to the formation of greigite as predicted, but rather pure pyrrhotite resulted. Other groups have been able to access greigite by decomposing $\mathrm{Fe}\left(\mathrm{S}_{2} \mathrm{CNR}_{2}\right)_{3}$, although in many cases with pyrrhotite impurities. , $^{8,36,37}$

Attempts are ongoing to better understand the molecule to materials mechanism as a pattern develops between the decomposition pathway(s) of a range of transition metal dithiocarbamate complexes in amine solutions. For work on the potential role of iron sulfides in prebiotic chemistry, ${ }^{25}$ the ability to prepare greigite samples of high purity and varying average sizes allows us to probe how the latter affects their activity and also the effects of doping other metal ions (especially nickel) into the greigite structure on activity.

\section{Experimental section}

\section{General procedures}

All manipulations were performed under a dry, oxygen-free dinitrogen atmosphere using standard Schlenk techniques or in a MBRAUN Unilab glovebox. All solvents used were stored in alumina columns and dried with anhydrous engineering equipment, such that the water concentration was 5-10 ppm. All other reagents were procured commercially from Aldrich and used without further purification. Microanalytical data was obtained at UCL. Thiuram disulfide 3 was prepared as previously reported. ${ }^{74}$

\section{Physical measurements}

${ }^{1} \mathrm{H}$ and ${ }^{13} \mathrm{C}\left\{{ }^{1} \mathrm{H}\right\}$ NMR spectra were obtained on either a Bruker Avance III 400 or Avance 600 spectrometers. All spectra were recorded using $\mathrm{CDCl}_{3}$ which was dried and degassed over molecular sieves prior to use; ${ }^{1} \mathrm{H}$ and ${ }^{13} \mathrm{C}\left\{{ }^{1} \mathrm{H}\right\}$ chemical shifts are reported relative to $\mathrm{SiMe}_{4}$. Mass spectra were obtained using either Micromass 70-SE spectrometer using Electron Ionisation (EI) or a Thermo Finnigan MAT900xp spectrometer using Fast Atom Bombardment (FAB) ionisation. Elemental analysis was carried using Elemental Analyser (CE-440) (Exeter Analytical Inc). Thermogravimetric analysis (TGA) was performed using a Netzsch STA 449C TGA system. Data was recorded from 25 to $600{ }^{\circ} \mathrm{C}$ with a constant heating rate of $10{ }^{\circ} \mathrm{C}$ per minute. XRD were measured on a Bruker AXS D4 diffractometer using $\mathrm{CuK \alpha}_{1}$ 
radiation. The diffraction patterns obtained were compared to database standards. For TEM characterisation a $4 \mu \mathrm{L}$ droplet of nanoparticle suspension (chloroform) was placed on a holey carbon-coated copper TEM grid and allowed to evaporate in air under ambient laboratory conditions for several minutes. TEM images were obtained using a JEOL-1010 microscope at $100 \mathrm{kV}$ equipped with a Gatan digital camera. HRTEM measurements were collected using a Jeol 2100 (high resolution) TEM with a $\mathrm{LaB}_{6}$ source operating at an acceleration voltage of $200 \mathrm{kV}$. Micrographs were taken on a Gatan Orius charge-coupled device (CCD).

\section{Synthesis and characterisation of $\left[\mathrm{Fe}\left(\mathrm{S}_{2} \mathrm{CNR}_{2}\right)_{3}\right](1)$}

$\left[\mathbf{F e}\left(\mathbf{S}_{2} \mathbf{C N M e}_{2}\right)_{3}\right](\mathbf{1 a}) .{ }^{54} \mathrm{NaS}_{2} \mathrm{CNMe}_{2}(4.30 \mathrm{~g}, 30 \mathrm{mmol})$ in water $(60 \mathrm{~mL})$ was added dropwise to a solution of $\mathrm{FeCl}_{3}(1.62 \mathrm{~g}, 10$ $\mathrm{mmol})$ in water $(50 \mathrm{~mL})$, whereupon a black precipitate formed. This mixture was vigorously stirred for $2 \mathrm{~h}$, filtered, washed with water $(3 \times 30 \mathrm{~mL})$ and evaporated to dryness. The resulting black powder was dissolved in $100 \mathrm{~mL}$ of $\mathrm{CH}_{2} \mathrm{Cl}_{2}$ and stirred with magnesium sulphate for $30 \mathrm{~min}$, after which it was filtered and the filtrate dried in vacuo. Yield $3.29 \mathrm{~g}, 79 \%$. Anal. calc. for $\mathrm{C}_{9} \mathrm{H}_{18} \mathrm{~N}_{3} \mathrm{~S}_{6} \mathrm{Fe}$ : C, 25.95; H, 4.36; N, 10.09. Found: C, 25.79; H, 4.37; N, 10.17. MS: $m / z 416\left[\mathrm{M}^{+}\right], 296\left[\mathrm{M}^{+}-\mathrm{C}_{3} \mathrm{H}_{6} \mathrm{NS}_{2}\right]$. IR $\left(\nu_{\max } \mathrm{cm}^{-1}\right): 1516(\mathrm{~s})[\mathrm{N}=\mathrm{C}], 972(\mathrm{~s}), 1247(\mathrm{~s})[\mathrm{C}=\mathrm{S}], 1137(\mathrm{~s})$ $\left[\mathrm{C}_{2} \mathrm{~N}\right]$.

$\left[\mathbf{F e}\left(\mathbf{S}_{2} \mathbf{C N E t}_{2}\right)_{3}\right](\mathbf{1 b})$. Prepared following the same method as with 1a, with the exception that $\mathrm{NaS}_{2} \mathrm{NCEt}_{2}(6.76 \mathrm{~g}, 30 \mathrm{mmol})$ was used. Yield $4.30 \mathrm{~g}, 86 \%$. Anal. calc. for $\mathrm{C}_{15} \mathrm{H}_{30} \mathrm{~N}_{3} \mathrm{~S}_{6} \mathrm{Fe}: \mathrm{C}$, 35.99; H, 6.04; N, 8.39. Found: C, 35.88; H, 6.01; N, 8.40. MS: $m / z$ $500\left[\mathrm{M}^{+}\right], 352\left[\mathrm{M}^{+}-\mathrm{C}_{5} \mathrm{H}_{10} \mathrm{NS}_{2}\right]$. IR $\left(\nu_{\max } \mathrm{cm}^{-1}\right): 1485(\mathrm{~s})[\mathrm{N}=\mathrm{C}]$, $994(\mathrm{~s}), 1270(\mathrm{~s})[\mathrm{C}=\mathrm{S}], 1133(\mathrm{~s})\left[\mathrm{C}_{2} \mathrm{~N}\right]$.

$\left[\mathrm{Fe}\left(\mathbf{S}_{2} \mathbf{C N}^{\mathrm{i}} \mathrm{Bu}_{2}\right)_{3}\right](\mathbf{1 c}) .{ }^{\mathrm{i}} \mathrm{Bu}_{2} \mathrm{NH}(5.24 \mathrm{~mL}, 30 \mathrm{mmol})$ was added to $\mathrm{NaOH}(1.20 \mathrm{~g}, 30 \mathrm{mmol})$ in water $(50 \mathrm{~mL})$. To this mixture $\mathrm{CS}_{2}$ $(1.80 \mathrm{~mL}, 30 \mathrm{mmol}$ ) was added dropwise over $10 \mathrm{~min}$ and the mixture stirred overnight. A solution of $\mathrm{FeCl}_{3}(1.62 \mathrm{~g}, 10 \mathrm{mmol})$ in water $(50 \mathrm{~mL})$ was added dropwise over $5 \mathrm{~min}$, whereupon a black precipitate formed. This mixture was vigorously stirred for $2 \mathrm{~h}$, filtered, washed with water $(3 \times 30 \mathrm{~mL})$ and evaporated to dryness. The resulting black powder was dissolved in $100 \mathrm{~mL}$ of $\mathrm{CH}_{2} \mathrm{Cl}_{2}$ and stirred with magnesium sulphate for $30 \mathrm{~min}$, after which the mixture was filtered and the filtrate dried in vacuo. Yield $5.55 \mathrm{~g}, 83 \%$. Anal. calc. for $\mathrm{C}_{27} \mathrm{H}_{54} \mathrm{~N}_{3} \mathrm{~S}_{6} \mathrm{Fe}$ : C, 48.48; H, 8.14; N, 6.23. Found: C, 48.52; H, 8.26; N, 6.23. MS: $m / z 669$ $\left[\mathrm{M}^{+}\right], 464\left[\mathrm{M}^{+}-\mathrm{C}_{9} \mathrm{H}_{18} \mathrm{NS}_{2}\right]$. IR $\left(\nu_{\max } \mathrm{cm}^{-1}\right): 1482(\mathrm{~s})[\mathrm{N}=\mathrm{C}], 992$ (s), $1244(\mathrm{~s})[\mathrm{C}=\mathrm{S}], 1145(\mathrm{~s})\left[\mathrm{C}_{2} \mathrm{~N}\right]$.

$\left[\mathrm{Fe}\left(\mathrm{S}_{2} \mathbf{C N M e B u}\right)_{3}\right](\mathbf{1 d})$. Prepared following the same method as with 1c, with the exception that MeBuNH $(3.55 \mathrm{~mL}, 30 \mathrm{mmol})$ was used. Yield $0.39 \mathrm{~g}, 43 \%$. Anal. calc. for $\mathrm{C}_{9} \mathrm{H}_{18} \mathrm{~N}_{3} \mathrm{~S}_{6} \mathrm{Fe}$ : C, 39.83; H, 6.69; N, 7.74. Found: C, 39.54; H, 6.83; N, 7.61. MS: $m / z$ $543\left[\mathrm{M}^{+}\right], 380\left[\mathrm{M}^{+}-\mathrm{C}_{6} \mathrm{H}_{12} \mathrm{NS}_{2}\right] . \mathrm{IR}\left(\nu_{\max } \mathrm{cm}^{-1}\right): 1496(\mathrm{~s})[\mathrm{N}=\mathrm{C}]$, $936(\mathrm{~s}), 1246(\mathrm{~s})[\mathrm{C}=\mathrm{S}], 1144(\mathrm{~s})\left[\mathrm{C}_{2} \mathrm{~N}\right]$.

\section{Synthesis and characterisation of $\left[\mathrm{Fe}\left(\mathrm{S}_{2} \mathrm{CNR}_{2}\right)_{2}(\mathrm{CO})_{2}\right]$ (2)}

$\left[\mathrm{Fe}(\mathrm{CO})_{2}\left(\mathrm{~S}_{2} \mathrm{CNMe}_{2}\right)_{2}\right](\mathbf{2 a}){ }^{60} \mathrm{Fe}(\mathrm{CO})_{4} \mathrm{I}_{2}$ was synthesised and used in situ. A solution of iodine (0.38 g, $1.5 \mathrm{mmol})$ in $\mathrm{Et}_{2} \mathrm{O}(10$ $\mathrm{mL})$ was added dropwise to a solution of $\mathrm{Fe}(\mathrm{CO})_{5}(0.20 \mathrm{~mL}, 1.5$ $\mathrm{mmol})$ also in $\mathrm{Et}_{2} \mathrm{O}(10 \mathrm{~mL})$. After stirring for $15 \mathrm{~min} \mathrm{Fe}(\mathrm{CO})_{4} \mathrm{I}_{2}$

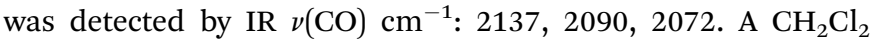
solution $(20 \mathrm{~mL})$ of $\left[\mathrm{H}_{2} \mathrm{NMe}_{2}\right]\left[\mathrm{S}_{2} \mathrm{CNMe}_{2}\right](0.50 \mathrm{~g}, 3.0 \mathrm{mmol})$ was added dropwise to $\mathrm{Fe}(\mathrm{CO})_{4} \mathrm{I}_{2}$ and the mixture stirred for $18 \mathrm{~h}$. The product was separated from $\left[\mathrm{H}_{2} \mathrm{NMe}_{2}\right] \mathrm{I}$ salt by cannula filtration and layered with heptane $(10 \mathrm{~mL})$ to yield coppercoloured crystals. Yield $0.24 \mathrm{~g}, 45 \%{ }^{1} \mathrm{H}$ NMR $\delta / \mathrm{ppm}\left(\mathrm{CDCl}_{3}\right)$ : $3.21\left(\mathrm{~s}, 6 \mathrm{H}, \mathrm{CH}_{3}\right), 3.28\left(\mathrm{~s}, 6 \mathrm{H}, \mathrm{CH}_{3}\right) .{ }^{13} \mathrm{C}\left\{{ }^{1} \mathrm{H}\right\} \mathrm{NMR} \delta / \mathrm{ppm}\left(\mathrm{CDCl}_{3}\right)$ : 38.3, $38.7\left(\mathrm{CH}_{3}\right), 206.9\left(\mathrm{CS}_{2}\right), 212.9(\mathrm{CO})$. Anal. calc. for $\mathrm{C}_{8} \mathrm{H}_{12}{ }^{-}$ $\mathrm{N}_{2} \mathrm{~S}_{4} \mathrm{O}_{2}$ Fe: C, 27.27; H, 3.43; N, 7.95. Found: C, 27.92; H, 3.65; N, 7.44. MS: $m / z 352\left[\mathrm{M}^{+}\right], 296\left[\mathrm{M}^{+}-2 \mathrm{CO}\right]$. IR $\nu(\mathrm{CO}) \mathrm{cm}^{-1}: 2023$, 1967.

$\left[\mathbf{F e}\left(\mathbf{S}_{2} \mathbf{C N E t}_{2}\right)_{2}(\mathbf{C O})_{2}\right](2 \mathrm{~b})$. To a solution of $\mathrm{Fe}(\mathrm{CO})_{4} \mathrm{I}_{2} \mathrm{a} \mathrm{CH}_{2} \mathrm{Cl}_{2}$ $(20 \mathrm{~mL})$ solution of $\left[\mathrm{NMe}_{4}\right]\left[\mathrm{S}_{2} \mathrm{CNEt}_{2}\right](1.07 \mathrm{~g}, 4.8 \mathrm{mmol})$ was added dropwise and the mixture stirred for $18 \mathrm{~h}$. The solid product was extracted in toluene $(10 \mathrm{~mL})$ and layered with heptane $(10 \mathrm{~mL})$ to give a copper-coloured oil. A dry powder was obtained by washing with pentane $(5 \mathrm{~mL})$. Yield $0.26 \mathrm{~g}, 42 \% .{ }^{1} \mathrm{H}$ NMR $\delta / p p m\left(\mathrm{CDCl}_{3}\right): 1.27\left(\mathrm{~m}, 12 \mathrm{H}, \mathrm{CH}_{2} \mathrm{CH}_{3}\right), 3.73(\mathrm{~m}, 8 \mathrm{H}$, $\left.\mathrm{CH}_{2} \mathrm{CH}_{3}\right) .{ }^{13} \mathrm{C}\left\{{ }^{1} \mathrm{H}\right\} \quad \mathrm{NMR} \quad \delta / \mathrm{ppm}\left(\mathrm{CDCl}_{3}\right): 12.6, \quad 12.6,12.8$ $\left(\mathrm{CH}_{2} \mathrm{CH}_{3}\right), 43.4,43.8,43.8\left(\mathrm{CH}_{2} \mathrm{CH}_{3}\right), 205.8\left(\mathrm{CS}_{2}\right), 213.1$ (CO). Anal. calc. for $\mathrm{C}_{12} \mathrm{H}_{20} \mathrm{~N}_{2} \mathrm{~S}_{4} \mathrm{O}_{2} \mathrm{Fe}$ : C, 35.29; H, 4.94; N, 6.86. Found: C, 36.00; H, 5.08; N, 6.76. MS: $m / z 393\left[\mathrm{M}^{+}-\mathrm{CH}_{3}\right] 352$ $\left[\mathrm{M}^{+}-2 \mathrm{CO}\right]$. IR $\nu(\mathrm{CO}) \mathrm{cm}^{-1}:$ 2022, 1966.

$\left[\mathrm{Fe}\left(\mathbf{S}_{2} \mathbf{C N}^{\mathrm{i}} \mathrm{Bu}_{2}\right)_{2}(\mathbf{C O})_{2}\right]$ (2c). To an $\mathrm{Et}_{2} \mathrm{O}$ solution of $\mathrm{Fe}(\mathrm{CO})_{4} \mathrm{I}_{2}$ was added an $\mathrm{Et}_{2} \mathrm{O}(10 \mathrm{~mL})$ solution of $\left[\mathrm{NMe}_{4}\right]\left[\mathrm{S}_{2} \mathrm{CN}^{\mathrm{i}} \mathrm{Bu}_{2}\right](1.00 \mathrm{~g}$, $3 \mathrm{mmol}$ ) and the mixture stirred for $18 \mathrm{~h}$. The solid product was extracted in hexane $(10 \mathrm{~mL})$ and cooled to $-10{ }^{\circ} \mathrm{C}$ to obtain copper-coloured crystals. Yield $0.34 \mathrm{~g}, 43 \%$. ${ }^{1} \mathrm{H}$ NMR $\delta / \mathrm{ppm}$ $\left(\mathrm{CDCl}_{3}\right): 0.93\left(\mathrm{~m}, 24 \mathrm{H}, \mathrm{CH}_{3}\right), 2.17(\mathrm{~m}, J=6.9 \mathrm{~Hz}, 2 \mathrm{H}, \mathrm{CH}), 2.23$ $(\mathrm{m}, J=6.9 \mathrm{~Hz}, 2 \mathrm{H}, \mathrm{CH}), 3.52\left(\mathrm{~m}, 8 \mathrm{H}, \mathrm{CH}_{2}\right) .{ }^{13} \mathrm{C}\left\{{ }^{1} \mathrm{H}\right\} \mathrm{NMR} \delta / \mathrm{ppm}$ $\left(\mathrm{CDCl}_{3}\right): 20.2,20.3,20.3,20.4\left(\mathrm{CH}_{3}\right), 27.1,27.2(\mathrm{CH}), 58.9,56.4$ $\left(\mathrm{CH}_{2}\right), 208.1\left(\mathrm{CS}_{2}\right), 213.1$ (CO). MS: $m / z 464\left[\mathrm{M}^{+}-2 \mathrm{CO}\right] . \mathrm{IR}$ $\nu(\mathrm{CO}) \mathrm{cm}^{-1}:$ 2026, 1974.

$\left[\mathrm{Fe}\left(\mathrm{S}_{2} \mathbf{C N M e B u}\right)_{2}(\mathbf{C O})_{2}\right](2 \mathrm{~d})$. To an $\mathrm{Et}_{2} \mathrm{O}$ solution of $\mathrm{Fe}(\mathrm{CO})_{4} \mathrm{I}_{2}$ a solution of $\left[\mathrm{NMe}_{4}\right]\left[\mathrm{S}_{2} \mathrm{CNMeBu}\right](0.75 \mathrm{~g}, 3 \mathrm{mmol})$ in $\mathrm{CH}_{2} \mathrm{Cl}_{2}(20$ $\mathrm{mL}$ ) was added dropwise and the mixture stirred for $15 \mathrm{~min}$. The product was extracted in toluene $(10 \mathrm{~mL})$ and layered with heptane $(10 \mathrm{~mL})$ but no crystals could be obtained from the oily product. Extraction with pentane $(5 \mathrm{~mL})$ yielded a brown powder after two weeks in the freezer. Yield $0.22 \mathrm{~g}, 34 \% .{ }^{1} \mathrm{H}$ NMR $\delta / p p m\left(\mathrm{CDCl}_{3}\right): 0.95\left(\mathrm{~m}, 6 \mathrm{H}, \mathrm{CH}_{2}\left(\mathrm{CH}_{2}\right)_{2} \mathrm{CH}_{3}\right), 1.50(\mathrm{~m}, 8 \mathrm{H}$, $\left.\mathrm{CH}_{2}\left(\mathrm{CH}_{2}\right)_{2} \mathrm{CH}_{3}\right), 3.19\left(\mathrm{~m}, 6 \mathrm{H}, \mathrm{NCH}_{3}\right), 3.60\left(\mathrm{~m}, 6 \mathrm{H}, \mathrm{CH}_{2}\left(\mathrm{CH}_{2}\right)_{2}-\right.$ $\left.\mathrm{CH}_{3}\right) \cdot{ }^{13} \mathrm{C}\left\{{ }^{1} \mathrm{H}\right\}$ NMR $\delta / p p m\left(\mathrm{CDCl}_{3}\right): 13.9,13.9,14.0\left(\left(\mathrm{CH}_{2}\right)_{3} \mathrm{CH}_{3}\right)$, 19.9, 20.0, $20.1\left(\mathrm{CH}_{2}\right), 29.0,29.1,29.2\left(\mathrm{CH}_{2}\right), 36.2,36.6,\left(\mathrm{CH}_{3}\right)$, 50.9, 51.1, $51.4\left(\mathrm{CH}_{2}\right), 206.5\left(\mathrm{CS}_{2}\right), 213.0(\mathrm{CO})$. Anal. calc. for $\mathrm{C}_{18} \mathrm{H}_{36} \mathrm{~N}_{2} \mathrm{~S}_{4} \mathrm{Ni}: \mathrm{C}, 38.53 ; \mathrm{H}, 5.54 ; \mathrm{N}, 6.42$. Found: C, 38.84; $\mathrm{H}$, 5.20; N, 6.03. MS: $m / z 381\left[\mathrm{M}^{+}-2 \mathrm{CO}\right]$. IR $\nu(\mathrm{CO}) \mathrm{cm}^{-1}: 2036$, 1967.

\section{Decomposition studies}

In a typical synthesis the dithiocarbamate complex ( $5 \mathrm{mM}$ ) was added to oleylamine $(20 \mathrm{~mL})$ in a three-neck round bottom flask attached to a water condenser and evacuated and refilled with nitrogen repeatedly for $c a$. 15 minutes. The solution was heated to $230{ }^{\circ} \mathrm{C}$ and held there for $1 \mathrm{~h}$. The mixture was allowed to cool 
to room temperature slowly, whereupon methanol $(80 \mathrm{~mL})$ was added with stirring. The mixture was centrifuged and the solution decanted leaving behind the resultant nanoparticles. This procedure was repeated three times and then the material was dried under vacuum. A picture of the apparatus used is given in the ESI.:

\section{XAS studies}

XAS spectra were acquired at the iron K-edge $(7112 \mathrm{eV})$ on the Dutch-Belgian EXAFS beamline, BM26A. ${ }^{78}$ Monochromatic radiation was supplied by a double $\mathrm{Si}(111)$ crystal, ion chambers were used to measure incident and transmitted beam intensities $\left(I_{0}\right.$ and $\left.I_{\mathrm{t}}\right)$, and fluorescence was measured using a 9 element germanium solid state detector. Solid 1c was diluted with polyvinylpyrrolidone, pelletized, and placed in the beam. Solutions of 1c were held within in situ liquid cells. The in situ liquid cell used was developed at UCL for synchrotron based experiments on liquid samples. Cartridge heaters embedded into the conductive cell body allow temperatures to reach up to $200{ }^{\circ} \mathrm{C}$, subject to pressure buildup of the system. The Kapton sealed reaction chamber holds $400 \mu \mathrm{L}$ of solution with a fixed path length of $2 \mathrm{~mm}$. Measurements were taken in fluorescence. The in situ liquid microtron cell was developed by Sample Environment at the ESRF for liquid experiments up to $260{ }^{\circ} \mathrm{C}$. With quartz cell windows and a $4 \mathrm{~mm}$ path length, the cell was used for measurements in transmission. XAS data was normalized and background subtracted using Horae Athena software. ${ }^{79}$ Linear combination analyses were also performed using Horae Athena. Detailed EXAFS analyses were performed on Excurve Version $9.273 .^{80}$

\section{Conflicts of interest}

There are no conflicts of interest to declare.

\section{Acknowledgements}

We thank the EPSRC for funding and beamline staff at Dubble, ESRF for their technical support and the Netherlands Organisation for Scientific Research (NWO) for making beam time available on the DUBBLE beamlines at the ESRF. WB's contribution is based upon work supported by Oak Ridge National Laboratory, managed by UT-Battelle, LLC, for the U.S. Department of Energy.

\section{References}

1 D. Rickard and G. W. Luther, Chem. Rev., 2007, 107, 514.

2 C. Di Giovanni, W. Wang, S. Nowak, J. Grene, L. Mouton, M. Giraud and C. Tard, ACS Catal., 2014, 4, 681.

3 K. Ramasamy, M. A. Malik, N. Revaprasadu and P. O'Brien, Chem. Mater., 2013, 25, 3551.

4 H. A. Macpherson and C. R. Stoldt, ACS Nano, 2012, 6, 8940.

5 D.-Y. Wang, Y.-T. Jiang, C.-C. Lin, S.-S. Li, Y.-T. Wang, C.-C. Chen and C.-W. Chen, Adv. Mater., 2012, 24, 3415.
6 A. K. Dutta, S. K. Maji, D. N. Srivastava, A. Mondal, P. Biswas, P. Paul and B. Adhikary, ACS Appl. Mater. Interfaces, 2012, 4, 1919.

7 G. H. Yue, P. X. Yan, L. S. Wang, W. Wang, Y. Z. Chen and D. L. Peng, Nanotechnology, 2008, 19, 195706.

8 M. Feng, Y. Lu, Y. Yang, M. Zhang, Y.-J. Xu, H.-L. Gao, L. Dong, W.-P. Xu and S.-H. Yu, Sci. Rep., 2013, 3, 2994.

9 Y.-S. Chang, S. Savitha, S. Sadhasivam, C.-K. Hsu and F.-H. Lin, J. Colloid Interface Sci., 2011, 363, 314.

10 Y.-W. Jun, J.-W. Seo and J. Cheon, Acc. Chem. Res., 2008, 41, 179.

11 W. Martin and M. J. Russell, Philos. Trans. R. Soc., B, 2003, 358, 59.

12 M. J. Russell and A. J. Hall, J. Geol. Soc., 1997, 154, 377.

13 M. J. Russell, R. M. Daniel, A. J. Hall and J. A. Sherringham, J. Mol. Evol., 1994, 39, 231.

14 M. J. Russell and W. Martin, Trends Biochem. Sci., 2004, 29, 358.

15 G. Wachtershauser, Chem. Biodiversity, 2007, 4, 584.

16 N. Lane and W. Martin, Cell, 2012, 151, 1406.

17 U. P. Apfel and W. Weigand, Angew. Chem., Int. Ed., 2011, 50, 4262.

18 H. Seino and M. Hidai, Chem. Sci., 2011, 2, 847.

19 W. Nitschke, S. E. McGlynn, E. J. Milner-White and M. J. Russell, Biochim. Biophys. Acta, Bioenerg., 2013, 1827, 871.

20 H. Dobbek, V. Svetlitchnyi, L. Gremer, R. Huber and O. Meyer, Science, 2001, 293, 1281.

21 I. Tsujisho, M. Toyoda and Y. Amao, Catal. Commun., 2006, 7, 173.

22 T. Reda, C. M. Plugge, N. J. Abram and J. Hirst, Proc. Natl. Acad. Sci. U. S. A., 2008, 105, 10654.

23 A. Alissandratos, H. K. Kim, H. Matthews, J. E. Hennessy, A. Philbrook and C. J. Easton, Appl. Environ. Microbiol, 2013, 79, 741.

24 H. Dobbek, V. Svetlitchnyi, J. Liss and O. Meyer, J. Am. Chem. Soc., 2004, 126, 5382.

25 A. Roldan, N. Hollingsworth, A. Roffey, H.-U. Islam, J. B. M. Goodall, C. R. A. Catlow, J. A. Darr, W. Bras, G. Sankar, K. B. Holt, G. Hogarth and N. H. de Leeuw, Chem. Commun., 2015, 51, 7501.

26 A. Yamaguchi, M. Yamamoto, K. Takai, T. Ishii, K. Hashimoto and R. Nakamura, Electrochim. Acta, 2014, 141, 311.

27 M. G. Vladimirov, Y. F. Ryzhkov, V. A. Alekseev, V. A. Bogdanovskaya, V. A. Otroshchenko and M. S. Kritsky, Origins of Life and Evolution of the Biosphere, 2004, 34, 347.

28 W. Heinen and A. M. Lauwers, Origins of Life and Evolution of the Biosphere, 1996, 26, 131.

29 P. D. Matthews, M. Akhtar, M. A. Malik, N. Revaprasadu and P. O'Brien, Dalton Trans., 2016, 456, 18803.

30 D.-W. Wang, Q.-H. Wang and T.-M. Wang, CrystEngComm, 2010, 12, 755.

31 X. F. Qian, X. M. Zhang, C. Wang, Y. Xie, W. Z. Wang and Y. T. Qian, Mater. Sci. Eng. B, 1999, 64, 170. 
32 J. H. L. Beal, S. Prabakar, N. Gaston, G. B. Teh, P. G. Etchegoin, G. Williams and R. D. Tilley, Chem. Mater., 2011, 23, 2514.

33 J. Puthussery, S. Seefeld, N. Berry, M. Gibbs and M. Law, J. Am. Chem. Soc., 2011, 133, 716.

34 W. Li, M. Döblinger, A. Vaneski, A. L. Rogach, F. Jäckel and J. Feldmann, J. Mater. Chem., 2011, 21, 17946.

35 H. Zhang, B.-R. Hyun, F. W. Wise and R. D. Robinson, Nano Lett., 2012, 12, 5856.

36 J. H. L. Beal, P. G. Etchegoin and R. D. Tilley, J. Solid State Chem., 2012, 189, 57.

37 P. V. Vanitha and P. O'Brien, J. Am. Chem. Soc., 2008, 130, 17256.

38 J. H. L. Beal, P. G. Etchegoin and R. D. Tilley, J. Phys. Chem. C, 2010, 114, 3817.

39 S. K. Maji, A. K. Dutta, P. Biswas, D. N. Srivastava, P. Paul, A. Mondal and B. Adhikary, Appl. Catal., A Gen., 2012, 419, 170.

40 A. L. Abdelhady, M. A. Malik, P. O'Brien and F. Tuna, J. Phys. Chem. C, 2012, 116, 2253.

41 W. Han and M. Gao, Cryst. Growth Des., 2008, 8, 1023.

42 Y. Zhang, Y. Du, H. Xu and Q. Wang, CrystEngComm, 2010, 12, 3658.

43 L. Zhu, B. J. Richardson and Q. Yu, Nanoscale, 2014, 6, 1029. 44 Y. Bi, Y. Yuan, C. L. Exstrom, S. A. Darveau and J. Huang, Nano Lett., 2011, 11, 4953.

45 B. Yuan, W. Luan and S.-T. Tu, Dalton Trans., 2012, 41, 772. 46 M. Uda, Z. Anorg. Allg. Chem., 1967, 543, 105.

47 G. Hogarth, Prog. Inorg. Chem., 2005, 53, 71.

48 B. L. Edgar, D. J. Duffy, M. C. Palazzotto and L. H. Pignolet, J. Am. Chem. Soc., 1972, 236, 1125.

49 A. K. M. Groves, N. Morrison and J. A. McCleverty, J. Organomet. Chem., 1975, 84, 5.

50 M. C. Palazzotto, D. J. Duffy, B. L. Edgar, L. Que and L. H. Pignolet, J. Am. Chem. Soc., 1973, 95, 4537.

51 H. Kunkely and A. Vogler, Inorg. Chem. Commun., 2002, 5, 730.

52 D. G. Holah and C. N. Murphy, Can. J. Chem., 1971, 49, 2726.

53 M. Akhtar, J. Akhter, M. A. Malik, P. O'Brien, F. Tuna, J. Raftery and M. Helliwell, J. Mater. Chem., 2011, 21, 9737.

54 A. H. White, R. Roper, E. Kokot, H. Waterman and R. L. Martin, Aust. J. Chem., 1964, 17, 294.

55 K. Gleu and R. Schwab, Angew. Chem., 1950, 62, 320.

56 J. P. J. Fackler and D. G. Holah, Inorg. Nucl. Chem. Lett., 1966, $2,251$.

57 R. H. Holm, L. H. Pignolet and R. A. Lewis, J. Am. Chem. Soc., 1971, 93, 360.
58 O. A. Ileperuma and R. D. Feltham, Inorg. Chem., 1975, 14, 3042.

59 B. L. Edgar, D. J. Duffy, M. C. Palazzotto and L. H. Pignolet, J. Am. Chem. Soc., 1973, 95, 1125.

60 F. A. Cotton and J. A. McCleverty, Inorg. Chem., 1964, 3, 1398. 61 W. K. Dean, J. Organomet. Chem., 1977, 135, 195.

62 A. J. Deeming, C. S. Forth and G. Hogarth, J. Organomet. Chem., 2006, 691, 79.

63 A. J. Deeming, C. S. Forth and G. Hogarth, J. Organomet. Chem., 2007, 692, 4000.

64 K.-B. Shiu, S.-J. Yu, Y. Wang and G.-H. Lee, J. Organomet. Chem., 2002, 650, 37.

65 M. Akhtar, M. A. Malik, F. Tuna and P. O'Brien, J. Mater. Chem. A, 2013, 1, 8766.

66 H.-U. Islam, A. Roffey, N. Hollingsworth, C. R. A. Catlow, M. Wolthers, N. H. de Leeuw, W. Bras, G. Sankar and G. Hogarth, J. Phys. Conf. Ser., 2013, 430, 012050.

67 L. I. Victoriano, Coord. Chem. Rev., 2000, 196, 383.

68 L. I. Victoriano, Polyhedron, 2000, 19, 2269.

69 M. M. Karim, M. N. Abser, M. R. Hassan, N. Ghosh, H. G. Alt, I. Richards and G. Hogarth, Polyhedron, 2012, 42, 84.

70 S. Åkerström and P. E. B. Lindahl, Acta Chem. Scand., 1962, 16, 1206.

71 J. S. J. Ricci, C. Eggers and I. Bernal, Inorg. Chim. Acta, 1971, 235, 97.

72 J. B. Zimmerman, T. W. Starinshak, D. L. Uhrich and N. V. Duffy, Inorg. Chem., 1977, 16, 3107.

73 X. D. Hu and H. Q. Zhang, Mater. Sci. Forum, 2011, 688, 301.

74 A. Roffey, N. Hollingsworth, H.-U. Islam, M. Mercy, C. R. A. Catlow, G. Sankar, N. H. de Leeuw and G. Hogarth, Nanoscale, 2016, 8, 11067.

75 N. Hollingsworth, A. Roffey, H.-U. Islam, M. Mercy, A. Roldan, W. Bras, M. Wolthers, C. R. A. Catlow, G. Sankar, G. Hogarth and N. H. de Leeuw, Chem. Mater., 2014, 26, 6281.

76 R. J. Butcher and E. Sinn, J. Am. Chem. Soc., 1976, 98, 2440. 77 R. Y. Saleh and D. K. Straub, Inorg. Chem., 1974, 13, 1559.

78 S. Nikitenko, A. M. Beale, A. M. J. van der Eerden, S. D. M. Jacques, O. Leynaud, M. G. O'Brien, D. Detollenaere, R. Kaptein, B. M. Weckhuysen and W. Bras, J. Synchrotron Radiat., 2008, 15, 632.

79 B. Ravel and M. Newville, J. Synchrotron Radiat., 2005, 12, 537.

80 N. Binsted, EXCURV98: CCLRC Daresbury Laboratory Computer Program, 1998. 